Article

\title{
The Effects of Corporate Social Responsibility Practices and Environmental Factors through a Moderating Role of Social Media Marketing on Sustainable Performance of Business Firms
}

\author{
Jaffar Abbas $1,+, * \mathbb{C}$, Shahid Mahmood ${ }^{2,+}$, Hashim Ali ${ }^{1,+}{ }^{+}$, Muhammad Ali Raza ${ }^{3}$, Ghaffar Ali ${ }^{2, *}$, \\ Jaffar Aman ${ }^{4}\left(\mathbb{D}\right.$, Shaher Bano ${ }^{4}\left(\mathbb{D}\right.$ and Mohammad Nurunnabi ${ }^{5,6}(\mathbb{D}$ \\ 1 School of Media and Communication (SMC), Antai College of Economics and Management (ACEM), \\ Shanghai Jiao Tong University (SJTU), No. 800 Dongchuan Road Minhang District, Shanghai 200240, China; \\ Alikhan@sjtu.edu.cn \\ 2 College of Management, Shenzhen University, No.3688 Nanhai Avenue, Nanshan District, \\ Shenzhen 518060, China; shahidmsf@outlook.com \\ 3 National College of Business Administration \& Economics (NCBA\&E), Sub-Campus, \\ Multan 60000, Pakistan; m.ali.raza.mba@outlook.com \\ 4 School of Sociology and Political Science, Shanghai University, No. 99 Shangda Road, Baoshan, \\ Shanghai 200240, China; Jaffara@shu.edu.cn (J.A.); sbano@t.shu.edu.cn (S.B.) \\ 5 St Antony's College, The University of Oxford, 62 Woodstock Road, Oxford OX2 6JF, UK; \\ mohammad.nurunnabi@sant.ox.ac.uk or mnurunnabi@psu.edu.sa \\ 6 Department of Accounting, Prince Sultan University, P.O. Box 66833, Riyadh 11586, Saudi Arabia \\ * Correspondence: Abbas512@sjtu.edu.cn (J.A.); alig@szu.edu.cn (G.A.) \\ † Jaffar Abbas, Shahid Mahmood, and Hashim Ali equally contributed as a first author to this work.
}

Received: 14 May 2019; Accepted: 13 June 2019; Published: 21 June 2019

\begin{abstract}
This precise study performed a focalized investigation to examine the association of environmental effects, new product development performance, superior customers' value, and corporate social responsibility (CSR) on sustainable performance. This research study aimed to investigate how social media marketing application moderates the association between corporate social responsibility and sustainable performance of the firms located in Multan Division, Pakistan. This study applied a simple random sampling approach to execute this research, and the authors sent a questionnaire with an invitation letter and informed consent form to 752 respondents. Based on 548 valid responses from the targeted population, the first step was to screen and analyze data through Statistical Package for the Social Sciences (SPSS-V25) and the Smart PLS V-3.2.8. The results indicated that corporate social responsibility presented a positive impact on firms' sustainable performance. The findings also revealed that social media marketing tools moderated the relationship between CSR and sustainable production of business firms. As a final point, the study only included respondents from Multan Division, therefore, limiting the generalizability of the findings to other Pakistani business firms. The implications of this study may provide further directions for researchers and academicians to consider the larger sample size and the addition of new variables in other regions worldwide. The findings are useful for filling the gap between the relationship of environmental effects, CSR, and social media marketing application to calculate the sustainable performance of business firms.
\end{abstract}

Keywords: corporate social responsibility; environmental effect; social media marketing; new product development; customer value performance; sustainable performance 


\section{Introduction}

In recent times, several scholars have emphasized corporate social responsibility (CSR) practices associated with business ground and have considered CSR as a useful research area for numerous businesses, practitioners, academicians, and managers. However, despite CSR applicability and multiple research surveys on this concept, there has not been a universal agreement on how we should conceptualize CSR [1]. The perception of CSR has been developed over the last 30 years to reside in positive and significant dynamic features in specific characteristics of organizational theory [2]. According to Famiyeh and Moir, CSR practices restrict firms from continuing the commitment of being socially responsible in contributing to communities and economic growth, which could, therefore, improve employees' and their families' life quality at large [2,3]. Measuring corporate social responsibility indicates how organizations and business firms connect with clienteles, suppliers, retailers, and other stakeholders. The environmental analysis shows how business activities emphasize the ideal habitat and identifies how their venture adds to the betterment of society by incorporating their business with social concerns [2,3]. Scholars found that there are numerous indications that CSR leads to customer loyalty and enhances corporate reputation. Branco and Rodrigues (2006) stated that corporate social responsibility signifies organizations' and business firms' commitment to contributing to economic growth and working on the well-being of employees, business managers, their families, the society in which they live, and the local community at large [4].

Typically, scholars categorize CSR practices into external, internal, and environmental responsibilities. Firms' interior obligations consider responsible practices related to employees health, safety, and general welfare to improve their life quality. Examples include employees' training, job participation, educational development programs, an appropriate environment at the workplace, work-life balance, corporate governance practices, and independent audits [5]. External responsibilities of business firms refer to the business assistance/aid offered to cultural and social activities in local communities and determining problems related to society and local community development [2]. The environmental responsibility of firms is comprised of business processes and practices, such as waste reduction, efficiency in energy and water use, recycling, monitoring, and re-using by-products; and making efforts to preserve the natural resources, all of which are pitched to diminish the adverse effects of the operations of firms [6,7]. Previous studies in developing countries have indicated how initiatives and practices of corporate social responsibility have contributed to resolving numerous problems, such as improving labor rights, combating child labor, tackling issues of unemployment, and successfully reducing environmental pollution [8,9]. Hence, it is time to establish institutions and structures which contribute to poverty eradication, social justice, community wellbeing, and environmental protection [10]. Firms can make it tremendously visible activities by building roads, hospitals, schools, or similar contributions [11]. Literature has evidenced gaps in social provision and corporate governance, and there is also a lack of organizations and intuitions which provide social goods. Under these circumstances, business firms are showing an inclination to do better by their communities to fill these literature gaps [12-14].

The emergence of social media technology has provided a platform for business firms to interact and communicate with customers, suppliers, retailers, and other stakeholders. This technology serves several purposes, including those related to communication and marketing activities. Social media marketing application typically facilitates information sharing, and the process of content generation by individuals and technological innovations has played an essential role in enhancing firms' performance [15]. Social media marketing use via desktop computers and mobile phones provides numerous economic openings for business organizations. Smart mobile phones, tablets, and computers are useful for allowing users to access digital media while they are "on the go," and they benefit business firms due to time-sensitive awareness and the location of their users [16,17]. Firms might benefit from social media applications through smartphones for marketing research activity, discounts, sales promotions, communication, informal employee learning, loyalty programs, relationship building, and organizational development $[15,18,19]$. Business firms can use social media 
marketing tools in two forms of communication. The first is company-to-customers, in which business firms may build a relationship to consumers based on its locations and offer reviews about the nearby neighborhoods. The second is the content generated by users [20]. Presently, in the age of technological advances and information technology evolution, internet use has changed the ways of communication and marketing activities. It has offered a platform to firms in maintaining commercial relationships with their consumers and other stakeholders. The invention of the internet has had a massive transformational power on human societies worldwide.

Technological advancements have helped build a platform which enables business firms to cash in on large populations and markets to sell their products and services. However, few studies have examined how social media marketing application interact with business-to-business (B2B), business-to-customer (B2C) marketing activities or strategies to improve firms' performance. Thus, social media technologies throughout business firms permit the development of marketing capabilities, the improvement of consumers' relationships, and the enhancement of customer satisfaction. The emergence of social customers who produce value-added contents through social media tools has challenged researchers, academicians, and practitioners of social media marketing to reconsider customer relationships. However, few studies have examined how social media marketing effects performance, thus, resource-based-view (RBV) studies have demonstrated that investments in social media marketing and technological advancement have typically created new capabilities which have ultimately enhanced business firm performance [21-25]. Past literature has shown that social media marketing capabilities [26], or "e-marketing capabilities" [25], and customers' relationship management capabilities positively influence both customer relationships and firm performance [27].

The concept of taking advantage of social media applications has been the top agenda for many business managers and executives in recent years [28]. Kaplan and Haenlein (2010, p. 62, 63) found that decision-makers, executives, consultants, and practitioners emphasize the identification of numerous ways to make profits by using applications of social media technology such as Facebook, Twitter, Second Life, Wikipedia, and YouTube [29]. Business networks' power and capacities may determine the survival or success of a firm's business ventures. Business networks provide advantages, added credibility, latest information, awareness, and exchanges of relationships through social media marketing application. Business networks also enable firms and entrepreneurs to access to numerous opportunities and resources that are indispensable and contribute to a firm's growth and sustainable performance [30]. Typically, social media tools help in creating and developing business contacts for the building of business networking, as well as participation in social events, social activities, conferences, and business meetings. Based on the past literature and the underlying assumptions linked with social media applications, it is recognized that firms use business networking relationships and contacts to stimulate and enhance economic openings for increasing profits in attaining sustainable performance [31,32].

Accordingly, the primary purpose of the study was to examine the effects of practices of corporate social responsibility and how social media marketing application helps firms in building new capabilities for marketing activity and the adoption of strategies to enhance a firm's performance. This study offers a conceptual model/framework by utilizing dynamic capabilities (DC) and the resource-based-view (RBV) theory to debate whether the investment in social media marketing tools might work as support for resource inputs for developing marketing-related skills [33]. The findings suggest that CSR practices are critical when business firms merge social media applications into their marketing strategies to increase customers' engagement and firm performance. This precise model also finds that social media applications play a significant determining the moderating role between corporate social responsibility practices and the sustainable production of business firms. These findings are insightful and provide numerous contributions to the literature on the relationship between CSR practices and firm performance, and they offer managerial insight into the efficiency of social media technology applications. This model also contributes to the existing CSR, social media marketing use, and firm performance literature by addressing the call to fill the gap and expand the generalizability of the 
association between CSR practices, social media marketing, and the sustainable performance of firms with cross-industry panel data sets. This study begins by presenting the conceptual background; then it describes its research procedure and the data set from the recruited respondents, then it shows the analysis and results, and, finally, it concludes with the study findings relating to theory and practices before clarifying the potential directions for future research.

Figure 1 presents an important economic region of south Punjab. We enriched the areas of this precise study by using the geographical identification of the study area of small business firms and small and medium enterprises (SMEs) locations by incorporating ArcGIS software (Esri, Redland, CA, USA), which is useful for presenting the study areas points on the map [34,35].

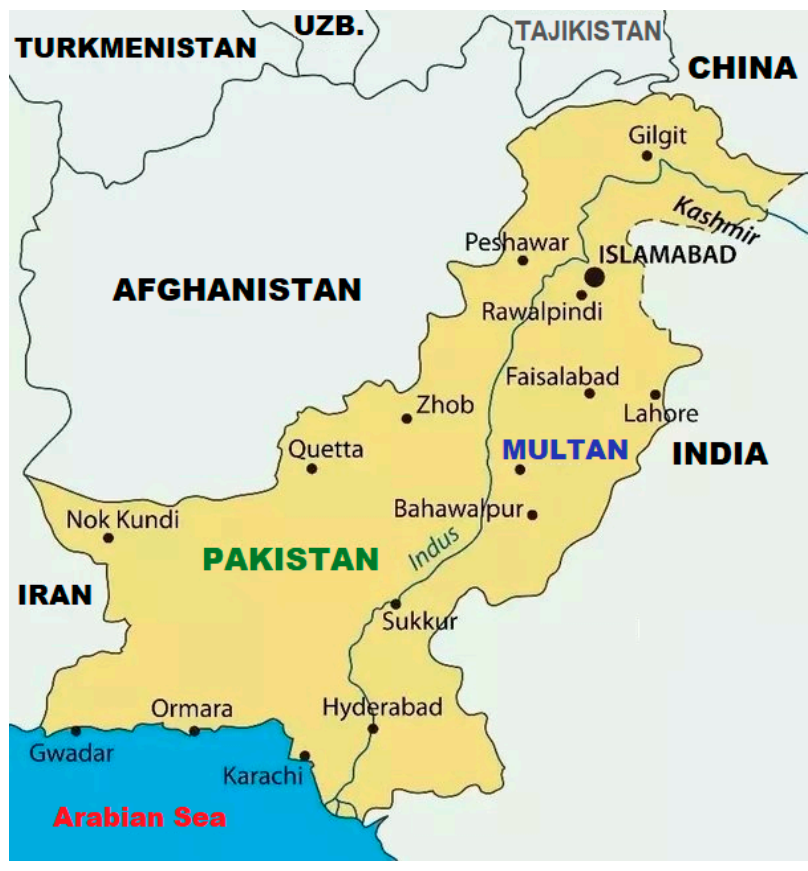

(a) Pakistan map showing study area (Source: Google)

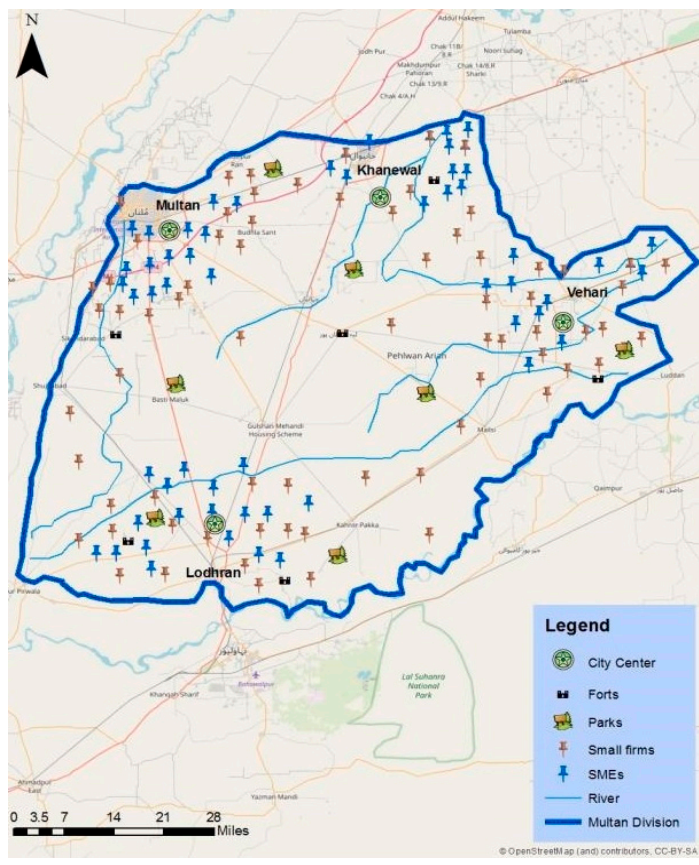

(b) Study area showing Multan Division in Pakistan

Figure 1. Study area showing Multan Division in Pakistan. The study covered small firms \& small and medium enterprises (SMEs).

\section{Literature Review and Hypotheses Development}

\subsection{Applications of Social Media Marketing Tools and Firm Performance}

Concerning firm performance, in recent years, social media marketing applications have become an integral part of our society, and the integration technological advances, web-technology, and cyberspace have become a common practice in several industries such as service firms, educational institutions, organizations, businesses and other stakeholders [36]. Organizations and business firms are empowered to communicate and interact with their customers, suppliers, retailers, and other stakeholders from anywhere by using social media via the internet at any time [16]. In the era of technological advances, several technological tools are available, and corporate trainers, academics, researchers, and other stakeholders can use these applications to obtain their goals. When firms use these tools efficiently, share knowledge, and create content, they are empowered to increase their profits significantly. These tools help to improve business firms' processes, which, in turn, enhances firms' performance [28]. Social media applications and business networking develop meaningful business ties for business firms, and these relationships and networks are significant sources of interaction for inaccessible and non-imitable business firms. Hence, social media marketing tools help developing businesses in networking, which might support firms in reducing the costs of a business transaction. 
By the support of above-cited literature, we recognize that business networks deliver a variety of benefits to firms that bring added-value to enhance sustainable performance, and they bolster the competitive business environment [37]. From the theoretical perspective, the resource-based view's central impression is that business firms make progress and compete in the market on building blocks of firms' resources and capabilities [37,38]. Likewise, business firms' intangible resources, such as business networks, are advantageous in increasing sustainable performance in a competitive and turbulent environment in the business industry [39].

\subsection{Organizational Performance}

Past literature demonstrated that the positive impact of internet use also supports business firms in several ways, and organizations are using technological tools to enhance CSR practices [40]. Applications of social media marketing expertise help business firms in attaining sustainable performance through export marketing [41], cost reduction, managerial and decision-making efficiency, revenue generation [42], enhancing and improving innovative business processes [43], reducing marketing activities cost, improving business firm image, improving consumers relationships, and gaining a competitive position [44]. Swierczek and Thi Phuong Thao (2008) explained that business firms use social media marketing and other technological tools for international communication as well as global interactions with their suppliers, consumers, and retailers [45]. Moen, Aspelund, and Koed Madsen (2008) stated that firms enhance market performance, communication technologies (ICT), and attain information through social media tools, which help firms to improve global business-to-business marketing events and activities [46]. The application of ICT helps business firms to obtain information on marketing activities, and it supports firms in executing their international and local market events. Preliminary studies indicated that firms build relationships through internet use and social media applications, and they also use these applications to enhance firm performance, time management, revenue generation, cost reduction, and building relationships with consumers and suppliers [47]. In an earlier study, Shuai and $\mathrm{Wu}$ (2011) found that the activities of internet marketing might improve business firms' operating processes performance, and they should implement more strategic methods of using the internet to enhance a firm's profitability and growth [48]. Rare studies examined social media applications' impact on sustainable organizational performance. Social media marketing strategies and technological advancements impact business firms performance as well as corporate social capital [47]. In the same way, Rodriguez, Peterson, and Ajjan (2015) identified that social media application used impacts consumers-oriented development and processes, which in turn enhances firms' sustainable performance $[49,50]$.

\subsection{Commitment to Providing Superior Customer Value}

Market-oriented firms have to significantly prioritize developing and delivering superior customer value [51]. At this phase of the operational process, business firms must disseminate, produce, and react to competitive marketing intelligence [52,53]. Usually, business firms contend that they possess an imperative market-orientation, and this is not merely enough to produce and offer superior value to customers. Thus, consumers do not buy a firm's offering. Instead, firms might attract customers by gaining knowledge about them, and they need to serve better by providing more excellent value [54]. In this sense, the real judge of superior value is the customer. For this situation, firms' understanding of the competitive market and found value refers to the critical point of firms' strategic choices associated with gaining the positioning benefits from developing specific values categories [55]. A firm's capacity for market sensing develops the structure of knowledge to enhance and recognize the actual market dynamism along with an information base for creating competencies to link the business firm more intensely with the business industry market and support firms in creating and delivering superior customer value [56]. As such, exclusive contributions offer a rare, valuable, excellent, and perfect information base, which is diminished with the absence of firms' precise deployment competencies [57]. Thus, highly market-oriented firms are capable of recognizing and organizing unique skills more 
professionally than other firms who are not more market-oriented. Business firms use strategic instruments and technological tools for communication purposes, and this shows a firm's commitment to offering superior customer values to their customers [58]. A firm's responsibility for providing excellent customer values is a critical challenge in marketing concepts and strategies, and this sheds light on what firms must do to remain competitive in consumer-focused market-driven economies. Delivering superior value to customers is the highest and top priority principal of business firms, as it is the value creation process that enhances firm profitability and performance [58,59]. Past literature has indicated that B2B salespeople' moral climate perceptions affect their perceived relationships with their sales supervisors and commitments to offering superior customer value $[60,61]$. Business firms want to understand and provide customer value to enhance a firm's sales, profitability, and sustainable performance [62-64].

\subsection{New Product Development}

New product development (NPD) is one of the most critical challenging process business firms face today [65]. In business and engineering firms, new product development typically covers a comprehensive process of launching and bringing a new product to the marketplace. The critical features of NPD are product design, quality, and price, along with numerous business considerations. Scholars have broadly described the concept of new product development as a transformation of the opportunities at the marketplace to launch a product for sale. Thus, NPD helps business firms to overcome an expensive process and common weaknesses to review the lack of an adequate new product development process [66]. The product has two categories-that of the of tangible-or having a physical shape —or intangible — that of service, experience, or belief. However, services and other operations are distinguished from physical "products." NPD requires a market survey and an understanding of consumers' needs or wants, the competitive business environment, and the situation of the focused market [67]. Firms adopt the best practices to eliminate communication barriers, as these are the key concerns for managing the process of NPD [68]. The process consists of different phases such as the strategy of new products/services, screening, idea generation, concept testing, NPD business analysis, testing development, a thorough marketing mix and the commercializing of the final product to the public or marketplace [67]. Past literature has indicated that researchers have discussed product innovation widely regarding the concept of new product development [66,69-72]. Previous studies identified that various scholars published several dozen articles in innovation and marketing literature that focused on the product launch issues faced by business firms [73-76]. Typically, risk and product launching costs should be closely associated with decision-making processes. In a lean launch, the fundamental principle based on an efficient business strategy of delaying the product, which suggests waiting until the product's latest probable point of marketing processing to reschedule changes in a product's inventory [76-79]. Usually, manufacturers might leverage new product development activities to increase product profitability and market share. Dwyer and Mellor (1991) described the four indicators that evaluate new product development: The overall assessment and general success (or failure probability), the innovation in design and other aspects, marketability, sales opportunity, and the profitability [80]. Lv and Zhang (2015) identified their indicators to measure NPD performance: Investment to growth rate, the ratio of investments, the sales ratio; sales growth rate, share in the market, and the ratio of market growth [81].

\subsection{Environmental Impact on Firm Performance}

Environmental uncertainty influences business firms' performance in the competitive business environment, and it concerns a lack of knowledge, which is a fundamental concept in management science research [82]. Firms facing an unstable business environment face challenges in predicting their external changes precisely because they lack updated business information in the competitive industry environment [83]. Various researchers defined the dimensions of environments on firms' sustainable performance; for instance, [84], scholars suggested that a firm's dynamics, kindness, and complexity 
influence the prevailing business environmental conditions. Daft (2004) acknowledged the unstable, turbulent, and intricate and pertinent factors for consideration on the business environment. Daft (2004) recognized complexity and volatility as relevant factors for review [83]. Complexity increases in large interactions between mechanisms of the environment, whereas a firm's dynamics develop in response to the changing positions of environmental elements $[84,85]$. These two factors make it tough for business firms to make decisions linked to a firm's required prompt action to grasp updated information to recover affected commercial openings [86]. Researchers debated and identified environmental uncertainty and instability in response to the degree of demand variation, product complexity, product variation, and the complexity of sourcing [87]. Some scholars identified the fact that environmental uncertainty has three indispensable sources: Tasks, processes of products, and organizational possibility [88]. Based on the literature, this research identified that environmental components such as the primary sources including demand, supply uncertainty, and product complexity also influence a firm's performance. Firms should consider exploitative activities for refining the existing capabilities to attain enhanced performance to increase profitability. In an uncertain business environment, consumers' demands, technological advancements, products, and materials derived from suppliers might change rapidly, and business firms need to respond quickly. Sharma (2011) identified that a proactive environmental strategy encourages and enhances financial outcomes by refining process efficiency [89]. An earlier study identified a significant association between a firm's financial performance and its practices of managing its business environment [90]. Proactive business firms that practice environmental management indicate enhanced operational and financial performances [91]. Many researchers have investigated eco-innovation and proactive environmental strategy as sources of competitive benefit [92,93]; however, few studies have examined how eco-innovation and a proactive environmental approach encourage firms' dynamic capabilities [94]. This research addresses the gap in the relationships between ecological impacts, social media marketing application, and firms' sustainable performance.

\subsection{Corporate Social Responsibility}

The literature indicates numerous theoretical viewpoints and debates to explain the core concepts of corporate social responsibility [95]. Carroll (1991) proposed the first definition of CSR among the prevailing views as a concept which signifies the ethical, economic, discretionary, business and the legal anticipations for business firms by viewing CSR perspectives as not only adding its contribution for business purposes but the social welfare perspective at large. Wood (1991) conceptualized CSR as organizations committed to specific values, procedures, policies, and contributions toward being a responsibility to society [96]. A previous study of Mohr et al. (2001) also identified that CSR is the commitment of organizations and business firms to reduce and eliminate any unsafe business practices and to increase a firm's contributions to human society [97]. The existence of CSR depends on organizations' responsibility when they consider the welfare and beneficial contributions to the community through economic, ethical, and helpful business applications practices, which are useful for stakeholders, suppliers, consumers, workers, community groups, and the business environment [97]. The concept of CSR appears through the commitment of organizations and business firms to consider a beneficial contribution to society or any other person who can be affected by their social implements and activities [98,99]. Accordingly, it is imperative to consider being socially responsible by offering a contribution to communities instead of focusing on being profit-oriented. By practicing CSR policies to protect the environmental good, a firm can execute its ethics to resolve social issues, which are firms' critical indicators being socially responsible. Organizations can express this through adhering to the policies and ethical standards by dealing with their different business stakeholders, retailers, suppliers, consumers, and employees. Past empirical and theoretical studies indicated that socially responsible firms perceive a positive image by its consumers and other stakeholders. Some studies identified that CSR practices revealed a significant influence on customer satisfaction [100]. Luo and Bhattacharya (2006) stated that practicing corporate social responsibility affects customer satisfaction 
directly [101]. Firms investing in CSR practices attain competitive advantages, which, in turn, enhance financial performance [102].

\subsection{Applications of Social Media Marketing via Technology}

Social media technology is a series of applications which are internet-based and built on the base of Web 2.0 technology that permits the development and exchange of content generated by users [103]. Several scholars defined social media applications in their ways [102]; however, Andreas Kaplan and Michael Heinlein developed an adequate description by distinguishing social media literature. Hansen et al. (2017) stated that social media technology (SMT) is a series of online tools which offer numerous communication and social interactions. Interestingly, applications of social media technology are attracting information seekers to attain updated information on available services and products; they intend to purchase, and this increases the buying intention of suppliers, retailers, and consumers [104]. Social media marketing helps business $\mathrm{f}$ and other stakeholders to accomplish various organizational objectives such as marketing, advertisements, customer service management, products branding activity, problem-solving, and human resources management $[19,105]$. The researchers of SMT consider it an efficient and advantageous platform for enterprises, organizations, individuals, and other stakeholders to connect, communicate, and interact with potential consumers, suppliers, and other stakeholders [106]. Online communities, including customers, retailers, suppliers, and other stakeholders, have extended the interconnectivity between business firms and empowered them in attaining speedy global communications [107]. Besides, social media marketing influences a firm's brand positioning, brand awareness, customer loyalty, and consumers' buying intentions and purchasing decisions $[19,108]$. The adaption of social media technology generates an extensive network among business organizations, customers, suppliers, retailers, and other stakeholders [109]. At present, business firms are integrating social media technology based on a business network approach by incorporating the benefits of business networking activities, and this has led to firms' superior performance [110]. However, previous studies neglected the benefit of online networking for small firms'/SMEs' performance [104,111,112], and these firms are the economic engines of several countries worldwide [36]. Few studies sought to examine social media marketing application effects on the performance of business firms [113]. Social media is a marvelous platform of free market research by focusing on consumers, retailers, and suppliers mutual interest evaluation, as well as the comments and posts on various social sites, and it offers conception to managers that can help in assessing the overall performance of a firm [114,115]. Thus, approaching and attracting customers, suppliers and other stakeholders globally will contribute to the concept of internationalization, and in turn, it will lead to a higher volume of sales, higher profitability, and improved firm performance. $[17,116,117]$.

Objective and Hypotheses of the Study

Objective

In this study, the primary purpose was to examine a relationship between corporate social responsibility and sustainable performance of the small firms through the moderating role of the social media marketing application.

Hypothesis 1 (H1). There is a significant positive association between corporate social responsibility and a firm's sustainable performance.

Hypothesis 2 (H2). Social media marketing application moderates the association between corporate social responsibility and a firm's sustainable performance.

Hypothesis 3 (H3). There is a significant positive impact on social media marketing application on a firm's sustainable performance. 


\subsection{Model of the Proposed Study}

This prospective study finds that social media marketing application plays a significant decisive role between corporate social responsibility and small business firms' performance. The study results provide numerous contributions to the existing literature and managerial insights into the efficacy of social media marketing application. This study also contributes to the research of corporate social responsibility and firm performance by giving answers to the call to increase the generalizability of the relationship between CSR, social media marketing application, and firm performance. The model contributes that CSR events typically lead to the favorable perception of social media marketing application as moderators between CSR and firm performance. However, despite SMT importance, very little empirical research has investigated the linkage between CSR practices, SMT use, and firm performance. Therefore, the authors designed this model to fill the existing literature gap in the current literature about the associations between social media marketing application, corporate social responsibility, and firm performance. This study presents a conceptual background and describes the research methodology and the data set of the selected respondents. In the next phase, the study performs an analysis of the received data and results. This study concludes with the findings and practice, and then it shares the possible directions for future research.

Figure 2 presents a study model after the in-depth review of the literature as already argued above to describe the study framework exhibited below.

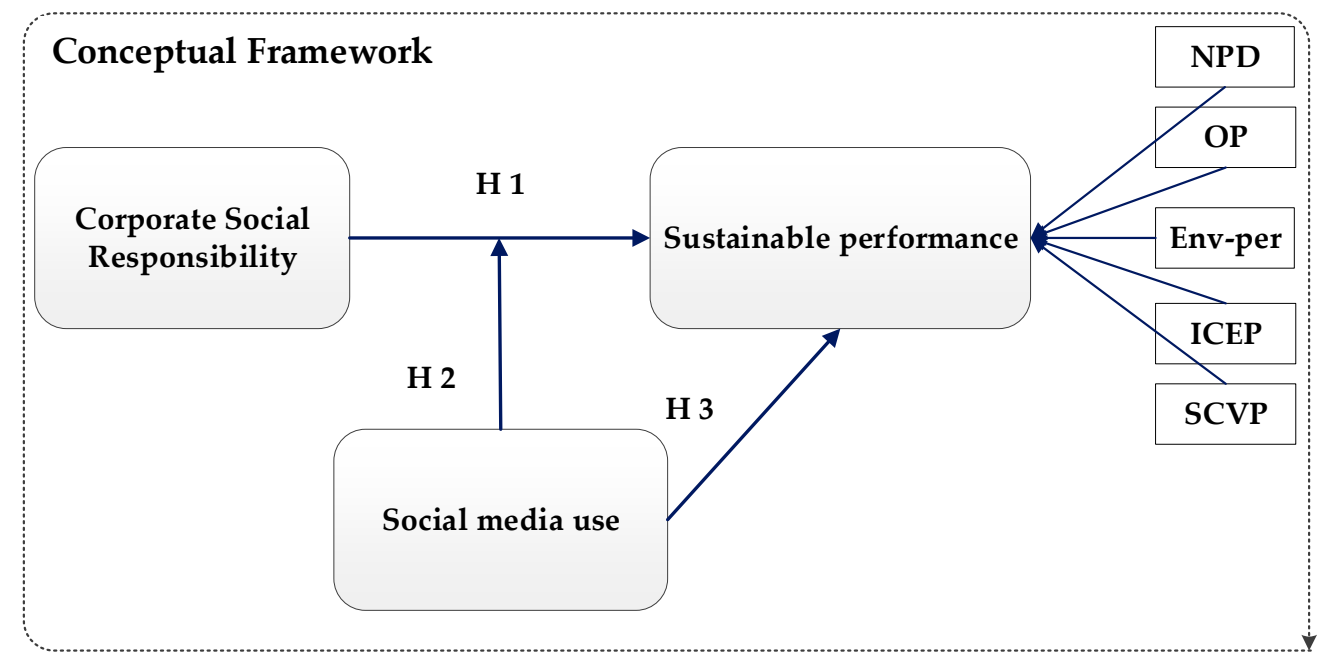

Figure 2. Conceptual framework.

Figure 2 demonstrates the conceptual framework of the proposed study. NPD stands for new product development [118], OP stands for organizations/firm performance [119], Env-per stands for firms' environmental performance [118], ICEP stands for information capital effective performance [118], and SCVP stands for superior customer value performance [118]. CSR stands for corporate social responsibility [119].

\section{Methods}

\subsection{Research Instruments}

The model of this precise research introduced three elements to the present framework. In this model, corporate social responsibility is the independent variable, a firm's sustainable performance is a dependent variable, and the application of social media marketing application is the moderating variable. This model adopted items of the survey from previous literature, with appropriate adjustments in mandatory sections. This study evaluated the effects of corporate social responsibility endogenous construct with a 4 item scale developed by Hanaysha (2017), and it is a second-order endogenous 
construct of CSR [119]. This model assessed the effects of social media marketing with a 13 item scale developed by Parveen et al. [43]. Social media marketing application is a second-order construct, which consists of three complementary dimensions: (a) Social media marketing tools for marketing activity, (b) social media marketing use for customer relations/services, and (c) social media marketing application for information accessibility [43]. Parveen et al. (2016) confirmed the reliability of social media marketing application, and the Cronbach alpha value was more significant than 0.70 and provided a sound and reliable assessment of social media marketing application. Besides, the study adopted a 5 item scale from the review of Mia et al. (2012) to assess a firm's environmental performance, a 7 item scale to evaluate the performance of new product development, and a four items scale to measure information capital effective performance. The model selected a 2 item scale for calculating customer value performance and a 9 item scale for assessing organizational performance, with there dimensions: Impact on cost reduction and enhanced information accessibility [119]. Spillan and Parnell (2006) stated that the assessment of a firm's sustainable performance presented adequate validity and reliability [120]. The Cronbach alpha coefficient indicated reliability of 0.787 for a firm's sustainable production, which is a substantial value. This study model incorporated a five-point Likert scale for the assessment of the performance of selected elements of the study, with "strongly disagree" representing one and "strongly agree" representing five.

Figure 3 displays the three steps of the data collection procedures. In the first phase, we selected the preliminary corporate social responsibility variable influencing the sustainable performance of the business firms. In the second phase, we designed a pilot study to test and obtain a clear understanding of questionnaire items' "reliability" and modified it accordingly. In the third and final step, we executed the survey and received feedback from the respondents.

Figure 3 presents the process of data collection [121].

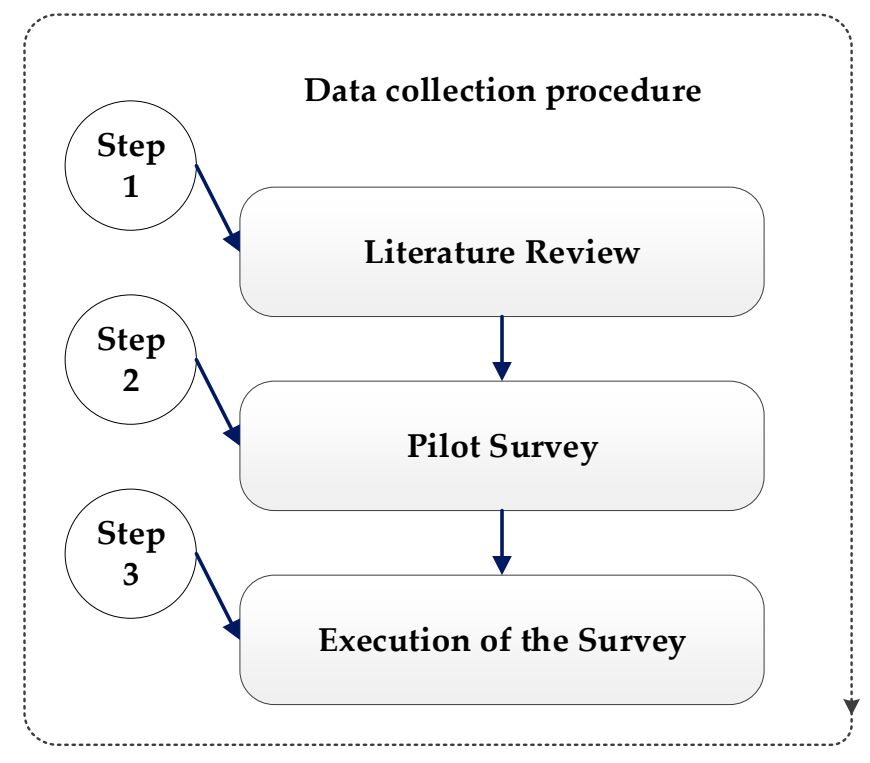

Figure 3. The procedure of data collection.

\subsection{Designing a Questionnaire}

We developed and distributed the revised version of the selected factors of the self-structured survey among the targeted population to receive the required data using a random sampling approach. We informed the respondents about the purpose of this research, and we assured the respondents that all the data elicited were strictly confidential. The questionnaire had two sections on the respondents' perceptions of the practices of corporate social responsibility and how social media marketing application moderates the relationship between CSR and small firms' performance. The survey also obtained the respondents' general information, such as gender, age, education, profession, and 
location in the questionnaire's first section. The survey's second section addressed the critical and influencing religiosity factors. The study invited respondents from the selected universe of study areas to answer questions on practices of corporate social responsibility, small firms' performance, and how social media marketing application. The questionnaire utilized a five-point Likert-scale requiring individuals to rate their agreement levels, with "strongly disagree" representing one and "strongly agree" representing five for assessing the performance of selected elements of the study.

\subsection{Size of the Targeted Population Sample}

The sample size of the population comprised of 548 complete/accurate responses and focused strictly on small business firms' in the district of Multan Division, Pakistan. The respondents were required to be educated, at least to a degree level. The researchers omitted uneducated people, as they were hesitant to answer questions during the pilot test, and they were unaware of the survey's importance. We educated the respondents about the survey's purpose, and the researchers gave the respondents 14 days to understand and fill out the survey.

\subsection{Data Processing of the Questionnaire's Feedback}

After receiving input from the targeted respondents, the researchers checked and screened all the questionnaires. Based on the completed and accurate responses, the researchers collected 508 adequately filled out surveys and scrutinized them to confirm data accuracy. This study processed the received data and analyzed them by applying the analytical tool smart-PLS 3.2.8. In the final step, the statistical analysis provided the interpreted results as a useful insight and valuable evidence for the evaluation of the underlying factors. Additionally, 15 experts on practices of corporate social responsibility, business firms' performance and social media marketing application, who had already contributed to the pilot study during the screening of crucial elements, were invited again to offer their valuable expertise and provide their opinions on the results.

\subsection{Sample and Procedures}

The prime focus of this precise study was on scrutinizing the effects of corporate social responsibility on firms' sustainable performance with the moderating impact of the social media marketing application. These SMEs/small firms operate in Multan division, Pakistan, with an employee strength of 15-35 [120,121]. This model adopted a cross-sectional research design for data collection to meet the study objective [122]. The proposed model of this study used a quantitative survey based on the self-administered questionnaires to assess the relationship between the study variables to attain the research objectives, and, eventually, this technique was deemed fit for the proposed model. The purpose of this survey was SMEs and small firms running their businesses in the adjacent districts of Multan Division of Pakistan, which is an important industrial area of the south region of the largest province of Punjab. Authors collected lists of SMEs/small firms registered with Multan Chamber of Commerce [123]. Authors distributed 752 questionnaires to respondents of SMEs/small firms to receive the required data. The response rate from the selected respondents was satisfactory $(72.86 \%)$.

\section{Results and Analysis}

A demographic analysis of the respondents showed that male participants (277) were in the majority $(50.55 \%)$, while the number of female respondents was $271(49.45 \%)$. The majority of participants were bachelor's (186:33.94\%), and master's degree holders (179:32.66\%). The majority of respondents were in the age of brackets of 25-29, 30-34, and 35-40. However, 60 respondents were 20-24 years old, which showed the lowest participation, as shown in Table 1. 
Table 1. Demographic analysis of the respondents.

\begin{tabular}{ccc}
\hline & Demographic Analysis \\
\hline Gender of Respondents & No. of Respondents & Percentage \\
\hline Male & 277 & $50.5 \%$ \\
Female & 271 & $49.5 \%$ \\
\hline \multicolumn{3}{c}{ Age of Respondents } \\
$25-24$ & 60 & $10.9 \%$ \\
$30-34$ & 149 & $27.2 \%$ \\
$35-40$ & 134 & $24.5 \%$ \\
$>41$ & 137 & $25.0 \%$ \\
& 68 & $12.4 \%$ \\
\hline Intermediate & Educational Background \\
Bachelor & 90 & $16.4 \%$ \\
Masters & 186 & $33.9 \%$ \\
MPhil & 179 & $32.7 \%$ \\
& 93 & $17.0 \%$ \\
\hline
\end{tabular}

This study measured mean scores (M), standard deviations (SDs), excess kurtosis, and skewness values, and all items of these scales showed consistent "reliability" and satisfactory results, as shown in Table 2.

Table 2. Mean (M), standard deviation (SD), kurtosis, and skewness values.

\begin{tabular}{|c|c|c|c|c|}
\hline Items & Mean & Std. Deviation & Excess Kurtosis & Skewness \\
\hline CSR-1 & 4.403 & 0.905 & -1.567 & 1.952 \\
\hline CSR-2 & 4.398 & 0.920 & -1.576 & 1.894 \\
\hline CSR-3 & 4.356 & 0.863 & -1.166 & 0.566 \\
\hline CSR-4 & 4.250 & 0.937 & -1.305 & 1.278 \\
\hline SM-1 & 4.144 & 1.085 & -1.267 & 0.710 \\
\hline SM-2 & 4.100 & 1.113 & -1.217 & 0.558 \\
\hline SM-3 & 4.083 & 1.147 & -1.352 & 0.987 \\
\hline SM-4 & 4.073 & 1.204 & -1.277 & 0.539 \\
\hline SM-5 & 4.104 & 1.201 & -1.263 & 0.458 \\
\hline SM-6 & 4.136 & 1.108 & -1.446 & 1.418 \\
\hline SM-7 & 4.055 & 1.224 & -1.286 & 0.519 \\
\hline SM-8 & 4.114 & 1.103 & -1.183 & 0.416 \\
\hline SM-9 & 4.118 & 1.106 & -1.285 & 0.797 \\
\hline SM-10 & 3.968 & 1.163 & -1.107 & 0.300 \\
\hline SM-11 & 3.985 & 1.156 & -0.976 & -0.133 \\
\hline SM-12 & 3.939 & 1.196 & -0.939 & -0.214 \\
\hline SM-13 & 3.933 & 1.207 & -1.102 & 0.234 \\
\hline NDPD-1 & 4.257 & 0.998 & -1.342 & 0.999 \\
\hline NDPD-2 & 4.254 & 0.999 & -1.321 & 0.934 \\
\hline NDPD-3 & 4.190 & 1.090 & -1.512 & 1.608 \\
\hline NDPD-4 & 4.230 & 1.098 & -1.539 & 1.534 \\
\hline NDPD-5 & 4.204 & 1.145 & -1.462 & 1.140 \\
\hline NDPD-6 & 4.266 & 1.036 & -1.669 & 2.335 \\
\hline NDPD-7 & 4.210 & 1.142 & -1.572 & 1.539 \\
\hline EnvPer-1 & 4.343 & 0.926 & -1.577 & 2.083 \\
\hline EnvPer-2 & 4.334 & 0.923 & -1.522 & 1.874 \\
\hline EnvPer-3 & 4.325 & 0.996 & -1.780 & 2.820 \\
\hline EnvPer-4 & 4.325 & 0.999 & -1.723 & 2.466 \\
\hline EnvPer-5 & 4.279 & 1.053 & -1.681 & 2.195 \\
\hline OP-1 & 4.347 & 0.927 & -1.584 & 2.095 \\
\hline OP-2 & 4.334 & 0.923 & -1.522 & 1.874 \\
\hline OP-3 & 4.321 & 0.995 & -1.773 & 2.808 \\
\hline $\mathrm{OP}-4$ & 4.330 & 1.000 & -1.733 & 2.485 \\
\hline OP-5 & 4.279 & 1.053 & -1.681 & 2.195 \\
\hline OP-6 & 4.370 & 0.944 & -1.924 & 3.722 \\
\hline OP-7 & 4.303 & 1.038 & -1.792 & 2.675 \\
\hline OP-8 & 4.339 & 0.912 & -1.506 & 1.820 \\
\hline
\end{tabular}


Table 2. Cont.

\begin{tabular}{ccccc}
\hline Items & Mean & Std. Deviation & Excess Kurtosis & Skewness \\
\hline OP-9 & 4.265 & 1.025 & -1.560 & 1.857 \\
ICEP-1 & 4.277 & 0.919 & -1.386 & 1.499 \\
ICEP-2 & 4.230 & 0.951 & -1.190 & 0.754 \\
ICEP-3 & 4.217 & 1.011 & -1.575 & 2.198 \\
ICEP-4 & 4.257 & 1.007 & -1.546 & 1.911 \\
CVP-1 & 4.263 & 0.990 & -1.328 & 0.946 \\
CVP-2 & 4.250 & 1.030 & -1.542 & 1.814 \\
\hline
\end{tabular}

Table 1 presents a comprehensive description of the descriptive statistical analysis showing the mean (M) and standard deviation (SD) scores, as well as the skewness and kurtosis values. The values of Table 2 reveal that the data present satisfactory results and shows normal distribution.

\subsection{PLS Analyses}

Researchers typically use a smart-partial least squares-structural equation modeling (PLS-SEM) technique for developing a theory in exploratory research [124]. Smart-PLS-SEM critical applications include confirmatory factor analysis, path coefficients analysis, multiple regression models, factor analysis, correlational structural models, and covariance's structural models [125]. Additionally, SEM permits linear relationships analysis between manifest variables and latent constructs. The Smart PLS-SEM refers to a multivariate statistical technique for evaluating the measurement model simultaneously with a structural model to indicate relationships between the constructs with its conforming indicators [126]. It also can produce available parameter estimates to assess associations between unobserved variables. Typically, the SEM method allows many associations for calculating and testing at once in a single projected model that has many links instead of investigating each connection individually. This study analyzed the hypothesized structural model of Figure 4 by using a smart-PLS-SEM technique, and this method is advantageous over other regression-based methods for evaluating different latent constructs with several manifest variables [125]. See Figure 4 below;

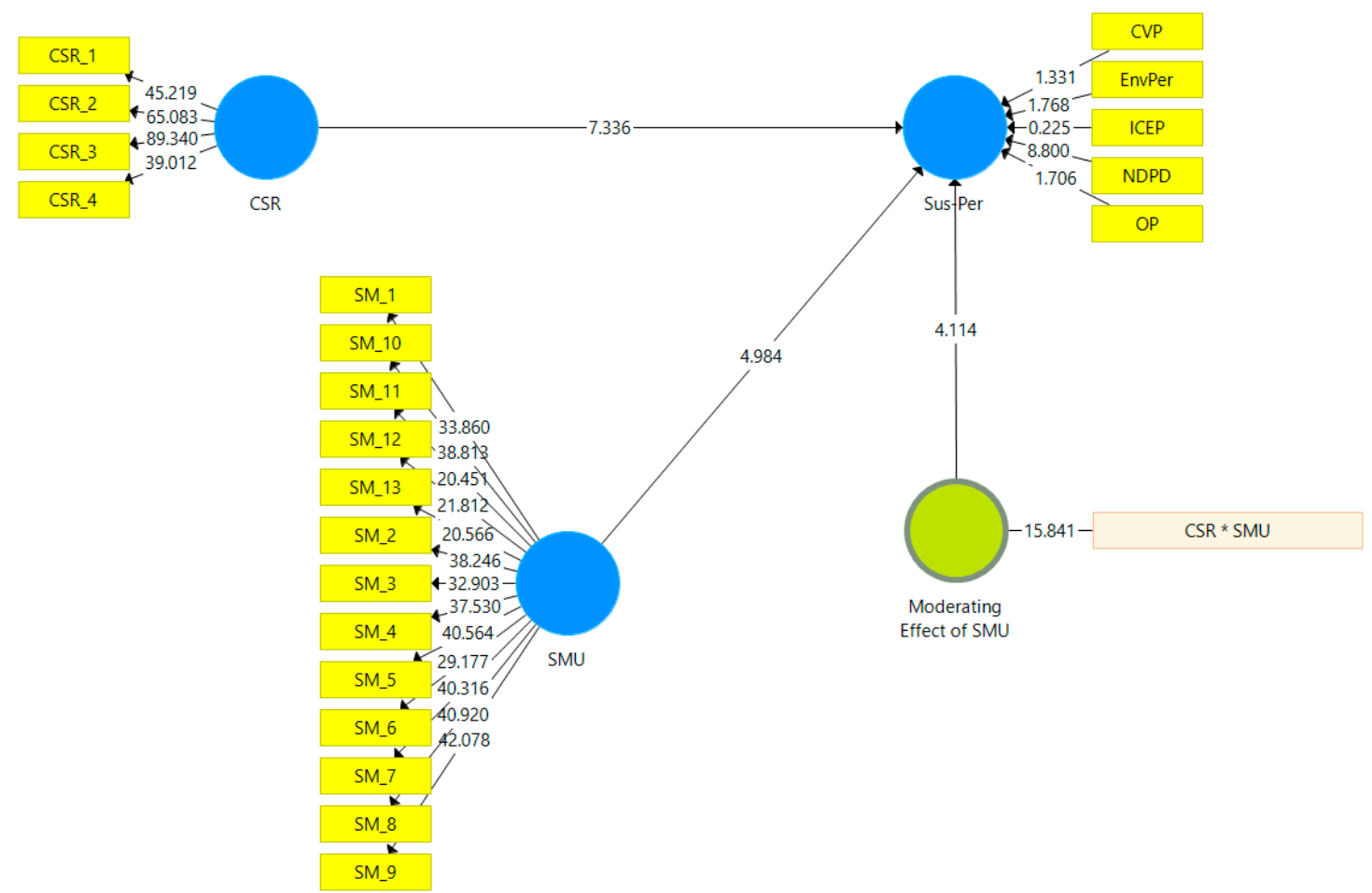

Figure 4. Shows the moderating role of a social media marketing application. 
The PLS-SEM research methodology is a robust, flexible, and superior tool to build an adequate statistical model, and the PLS-SEM feature helps in achieving the predicted objective $[125,127]$. Wan Afthanorhan [128] and Astrachan et al. [129] emphasized that a reliable and valid confirmatory factor analysis is achievable by using PLS-SEM path modeling. Consistent with the above arguments, PLS-SEM is a statistical tool that has been used by several researchers in various research areas in social sciences, including business research [130]. Moreover, PLS-SEM explicitly permits the testing of complex models which have multi-level effects; for instance, a moderating/mediating role and other complex models' variables relationships [125]. This study applied smart-PLS -SEM V-3.2.8 for data analysis and for calculating loadings, path coefficients, and weights. The study incorporated the bootstrapping technique to determine significance levels [130].

\subsection{Evaluation of Outer Measurement Model_Validity and "Reliability"}

This study evaluated the quality and merit of measurement goodness to confirm the validity and "reliability" of the analysis process output by using the PLS-SEM technique. Based on Hair et al. $[126,131]$, this study assessed an individual item's "reliability," discriminant validity, and concurrent validity before testing the hypotheses of the designed model. Before running the complete analysis, we measured the "reliability" and validity of the current model. In this model, the first-order constructs used were reflective, and we estimated the "reliability" of each item for internal consistency. In a reflective construct, the "reliability" of the individual indicator should be higher than 0.70 , and loading was significant at the level of $\alpha=0.05$. This model revealed a composite "reliability" higher than 0.70 , and the average variance extracted (AVE) derived over a threshold level of 0.5. Accordingly, results from the convergent validity level confirmed this model. This study used the smart-PLS algorithm to ascertain each item's "reliability" and the model's measurement assessment, as indicated in Figure 4. Hence, the indicator "reliability" examined the outer loadings of each measurement intended to measure a construct [126]. Composite "reliability" (CR) is the most common indicator to check the "reliability" of the internal consistency in the field of social sciences, and we applied this technique in this study [132]. Here, the composite "reliability" indicator showed that it was suitable to use PLS-SEM in this study [126].

Convergent validity presents the validity of constructs that measure how a specific measurement truly measures the construct that was intended to assess/calculate, and it displays a positive correlation with other alternative analyses of the same construct. Hence, it shows the degree of correlation among the identical construct measures [126]. Hair et al. [126] recommended a comprehensive research method of AVE for verifying the convergent validity for construct levels $[126,131]$. The loading values used were set to 0.4 according to the recommendations of Hair et al. The AVE value was set to 0.5, whereas the composite "reliability" displayed value of 0.7 [126]. Accordingly, in this study, we followed the recommended PLS-SEM method based on previous literature, which suggested the approach of using repeated indicators of the model. Table 3 below shows that the measurement model's results exceeded the recommended values, which indicates that convergence validity is sufficient. First, we checked the cross-loadings of all the constructs. Second, we used the most common criterion method for the Fornell-Lacker criterion technique. The square root of all constructs of AVEs values must be within the highest correlational matrix with any other construct. The values in Table 2 confirm that, in our model, the discriminant validity had fallen. In spite of this fact, these two methodologies are convenient methods for measuring, assessing, and evaluating the discriminant-validity in variance-based structural-equations modeling (see Table 3). 
Table 3. The measurement model displays a convergent validity, alpha $(\alpha)$, and "reliability."

\begin{tabular}{|c|c|c|c|c|c|c|}
\hline Constructs & Items & Loadings & $\begin{array}{c}\text { Cronbach's } \\
\text { Alpha }(\alpha)\end{array}$ & CR & AVE & $\begin{array}{l}\text { Discriminant } \\
\text { Validity }\end{array}$ \\
\hline \multirow[t]{4}{*}{ CSR } & CSR-1 & 0.845 & 0.875 & 0.915 & 0.729 & YES \\
\hline & CSR-2 & 0.875 & & & & \\
\hline & CSR-3 & 0.893 & & & & \\
\hline & CSR-4 & 0.799 & & & & \\
\hline \multirow[t]{2}{*}{ SCVP } & CVP-1 & 0.704 & 0.868 & 0.871 & 0.771 & YES \\
\hline & CVP-2 & 0.889 & & & & \\
\hline \multirow[t]{5}{*}{ Env-per } & Env-per-1 & 0.870 & 0.820 & 0.906 & 0.658 & YES \\
\hline & Env-per-2 & 0.799 & & & & \\
\hline & Env-per-3 & 0.806 & & & & \\
\hline & Env-per-4 & 0.807 & & & & \\
\hline & Env-per-5 & 0.824 & & & & \\
\hline \multirow[t]{4}{*}{ ICEP } & ICEP-1 & 0.804 & 0.787 & 0.871 & 0.629 & YES \\
\hline & ICEP-2 & 0.789 & & & & \\
\hline & ICEP-3 & 0.811 & & & & \\
\hline & ICEP-4 & 0.784 & & & & \\
\hline \multirow[t]{7}{*}{ NPD } & NPD_1 & 0.897 & 0.798 & 0.919 & 0.618 & YES \\
\hline & NPD_2 & 0.812 & & & & \\
\hline & NPD_3 & 0.728 & & & & \\
\hline & NPD_4 & 0.772 & & & & \\
\hline & NPD_5 & 0.831 & & & & \\
\hline & NPD_6 & 0.743 & & & & \\
\hline & NPD_7 & 0.813 & & & & \\
\hline \multirow[t]{9}{*}{$\mathrm{OP}$} & OP_1 & 0.911 & 0.787 & 0.927 & 0.586 & YES \\
\hline & OP_2 & 0.799 & & & & \\
\hline & OP_3 & 0.741 & & & & \\
\hline & $\mathrm{OP} \_4$ & 0.776 & & & & \\
\hline & OP_5 & 0.817 & & & & \\
\hline & OP_6 & 0.716 & & & & \\
\hline & OP_7 & 0.787 & & & & \\
\hline & OP_8 & 0.720 & & & & \\
\hline & OP_9 & 0.739 & & & & \\
\hline \multirow[t]{13}{*}{ SMTU } & SMTU1 & 0.929 & 0.747 & 0.939 & 0.543 & YES \\
\hline & SMTU2 & 0.797 & & & & \\
\hline & SMTU3 & 0.742 & & & & \\
\hline & SMTU4 & 0.766 & & & & \\
\hline & SMTU5 & 0.773 & & & & \\
\hline & SMTU6 & 0.728 & & & & \\
\hline & SMTU7 & 0.794 & & & & \\
\hline & SMTU8 & 0.779 & & & & \\
\hline & SMTU9 & 0.781 & & & & \\
\hline & SMTU10 & 0.77 & & & & \\
\hline & SMTU11 & 0.631 & & & & \\
\hline & SMTU12 & 0.641 & & & & \\
\hline & SMTU13 & 0.590 & & & & \\
\hline
\end{tabular}

Note 1: ${ }^{*} p<0.05 ; * * p<0.01 ; * * *<0.001$; Note 2: Statistical significance was determined by measuring Cronbach's alpha $(\alpha)$ reliability. $C R=$ composite-reliability, and AVE = average-variance-extracted and outer-loading $(\mathrm{OL})$, SMTU = social media marketing application, $\mathrm{CSR}=$ corporate social responsibility, SCVP $=$ superior customer value performance, Env-per $=$ environmental performance, $\mathrm{ICEP}=$ information capital effective performance, $\mathrm{OP}=$ organizational performance, and NPD = new product development.

For details, see Table 4 below. 
Table 4. Displays discriminant validity analysis (first-order).

\begin{tabular}{cccccccc}
\hline Variables & CSR & SCVP & Env-per & ICEP & NPD & OP & SMTU \\
\hline CSR & $\mathbf{0 . 8 5 4}$ & & & & & & \\
SCVP & 0.549 & $\mathbf{0 . 8 7 8}$ & & & & & \\
Env-per & 0.287 & 0.472 & $\mathbf{0 . 8 1 1}$ & & & & \\
ICEP & 0.211 & 0.409 & 0.271 & $\mathbf{0 . 7 9 3}$ & & & \\
NPD & 0.632 & 0.764 & 0.549 & 0.419 & $\mathbf{0 . 7 8 6}$ & & \\
OP & 0.444 & 0.62 & 0.743 & 0.334 & 0.632 & $\mathbf{0 . 7 6 5}$ & $\mathbf{0 . 7 3 7}$ \\
SMTU & 0.734 & 0.537 & 0.405 & 0.335 & 0.645 & 0.524 & \\
\hline
\end{tabular}

Note 1. ${ }^{*} p<0.05 ; * * p<0.01 ;{ }^{* * *} p<0.001$; CSR $=$ corporate social responsibility, SCVP = superior customer value performance, Env-per = environmental performance, ICEP = information capital effective performance, NPD = new product development, $\mathrm{OP}=$ organizational performance, and SMTU = social media marketing application (see Table 4).

\subsection{Graphical Representation of Construct Validity and "Reliability"}

Table 5 below shows outer loadings of corporate social responsibility (CSR), customer value performance (CVP), environmental performance (ENV), new product development (NPD), organizational performance (OP), and social media marketing application (see Table 5).

Table 5. Presents outer loadings of corporate social responsibility (CSR), customer value performance $(\mathrm{CVP})$, environmental performance (ENV), new product development (NPD), organizational performance (OP), and social media marketing application (SMTU).

\begin{tabular}{|c|c|c|c|c|c|c|c|}
\hline Constructs & CSR & CVP & ENV & ICEP & NDP & OP & SMTU \\
\hline CSR-1 & 0.845 & 0.360 & 0.215 & 0.175 & 0.447 & 0.331 & 0.672 \\
\hline CSR-2 & 0.875 & 0.445 & 0.247 & 0.184 & 0.527 & 0.41 & 0.693 \\
\hline CSR-3 & 0.893 & 0.483 & 0.298 & 0.214 & 0.601 & 0.402 & 0.64 \\
\hline CSR-4 & 0.799 & 0.582 & 0.214 & 0.146 & 0.573 & 0.368 & 0.502 \\
\hline CVP-1 & 0.462 & 0.868 & 0.384 & 0.354 & 0.624 & 0.593 & 0.472 \\
\hline CVP-2 & 0.501 & 0.889 & 0.443 & 0.364 & 0.715 & 0.501 & 0.472 \\
\hline EnvPer-1 & 0.242 & 0.410 & 0.820 & 0.248 & 0.433 & 0.608 & 0.312 \\
\hline EnvPer-2 & 0.218 & 0.356 & 0.799 & 0.198 & 0.382 & 0.578 & 0.299 \\
\hline EnvPer-3 & 0.204 & 0.387 & 0.806 & 0.205 & 0.429 & 0.597 & 0.328 \\
\hline EnvPer-4 & 0.25 & 0.423 & 0.807 & 0.221 & 0.506 & 0.623 & 0.334 \\
\hline EnvPer-5 & 0.243 & 0.337 & 0.824 & 0.222 & 0.468 & 0.605 & 0.369 \\
\hline ICEP-1 & 0.167 & 0.291 & 0.201 & 0.787 & 0.317 & 0.238 & 0.265 \\
\hline ICEP-2 & 0.182 & 0.359 & 0.224 & 0.789 & 0.340 & 0.270 & 0.278 \\
\hline ICEP-3 & 0.133 & 0.290 & 0.241 & 0.811 & 0.324 & 0.260 & 0.253 \\
\hline ICEP-4 & 0.179 & 0.344 & 0.196 & 0.784 & 0.343 & 0.287 & 0.262 \\
\hline NDPD-1 & 0.494 & 0.558 & 0.406 & 0.352 & 0.798 & 0.489 & 0.565 \\
\hline NDPD-2 & 0.490 & 0.650 & 0.460 & 0.326 & 0.812 & 0.532 & 0.542 \\
\hline NDPD-3 & 0.380 & 0.578 & 0.459 & 0.329 & 0.728 & 0.500 & 0.477 \\
\hline NDPD-4 & 0.511 & 0.603 & 0.479 & 0.330 & 0.772 & 0.523 & 0.490 \\
\hline NDPD-5 & 0.536 & 0.648 & 0.498 & 0.345 & 0.831 & 0.541 & 0.505 \\
\hline NDPD-6 & 0.471 & 0.531 & 0.339 & 0.307 & 0.743 & 0.409 & 0.447 \\
\hline NDPD-7 & 0.563 & 0.630 & 0.392 & 0.323 & 0.813 & 0.491 & 0.525 \\
\hline OP-1 & 0.349 & 0.623 & 0.504 & 0.294 & 0.470 & 0.787 & 0.410 \\
\hline OP-2 & 0.338 & 0.464 & 0.587 & 0.221 & 0.507 & 0.799 & 0.400 \\
\hline OP-3 & 0.286 & 0.480 & 0.540 & 0.251 & 0.419 & 0.741 & 0.410 \\
\hline OP-4 & 0.373 & 0.444 & 0.600 & 0.261 & 0.502 & 0.776 & 0.423 \\
\hline OP-5 & 0.369 & 0.509 & 0.652 & 0.257 & 0.521 & 0.817 & 0.423 \\
\hline OP-6 & 0.298 & 0.394 & 0.526 & 0.220 & 0.440 & 0.716 & 0.373 \\
\hline OP-7 & 0.349 & 0.510 & 0.586 & 0.211 & 0.505 & 0.787 & 0.373 \\
\hline OP-8 & 0.333 & 0.398 & 0.593 & 0.243 & 0.471 & 0.720 & 0.385 \\
\hline OP-9 & 0.349 & 0.443 & 0.522 & 0.339 & 0.506 & 0.739 & 0.408 \\
\hline
\end{tabular}


Table 5. Cont.

\begin{tabular}{cccccccc}
\hline Constructs & CSR & CVP & ENV & ICEP & NDP & OP & SMTU \\
\hline SMTU-1 & 0.524 & 0.328 & 0.276 & 0.250 & 0.447 & 0.34 & $\mathbf{0 . 7 4 7}$ \\
SMTU-2 & 0.602 & 0.442 & 0.318 & 0.242 & 0.466 & 0.417 & $\mathbf{0 . 7 9 7}$ \\
SMTU-3 & 0.531 & 0.385 & 0.298 & 0.246 & 0.429 & 0.349 & $\mathbf{0 . 7 4 2}$ \\
SMTU-4 & 0.554 & 0.408 & 0.312 & 0.246 & 0.450 & 0.392 & $\mathbf{0 . 7 6 6}$ \\
SMTU-5 & 0.572 & 0.427 & 0.331 & 0.249 & 0.483 & 0.480 & $\mathbf{0 . 7 7 3}$ \\
SMTU-6 & 0.563 & 0.382 & 0.300 & 0.237 & 0.401 & 0.377 & $\mathbf{0 . 7 2 8}$ \\
SMTU-7 & 0.624 & 0.420 & 0.275 & 0.276 & 0.484 & 0.382 & $\mathbf{0 . 7 9 4}$ \\
SMTU-8 & 0.554 & 0.403 & 0.303 & 0.195 & 0.599 & 0.395 & $\mathbf{0 . 7 7 9}$ \\
SMTU-9 & 0.565 & 0.413 & 0.278 & 0.271 & 0.478 & 0.414 & $\mathbf{0 . 7 8 1}$ \\
SMTU-10 & 0.496 & 0.427 & 0.314 & 0.245 & 0.436 & 0.362 & $\mathbf{0 . 7 7}$ \\
SMTU-11 & 0.490 & 0.321 & 0.268 & 0.29 & 0.515 & 0.346 & $\mathbf{0 . 6 3 1}$ \\
SMTU-12 & 0.478 & 0.380 & 0.279 & 0.210 & 0.491 & 0.353 & $\mathbf{0 . 6 4 1}$ \\
SMTU-13 & 0.441 & 0.408 & 0.344 & 0.262 & 0.526 & 0.402 & $\mathbf{0 . 5 9 0}$ \\
\hline
\end{tabular}

Note: Outer loading values of the model; $C S R=$ corporate social responsibility, SCVP $=$ superior customer value performance, Env-per = environmental performance, ICEP = information capital effective performance, NPD = new product development, $\mathrm{OP}=$ organizational performance, and SMTU = social media marketing application.

Table 6 below displays detailed information.

Table 6. Displays convergent validity/correlational matrix of Env-per, NPD, OP, information capital effective performance (ICEP), and superior customer value performance (SCVP).

\begin{tabular}{cccccc}
\hline \multicolumn{5}{c}{ Convergent Validity/Correlational Matrix } \\
\hline Items & ENV & NPD & OP & ICEP & SCVP \\
\hline Env-per (EVN) & 1 & & & \\
NPD & $0.470^{* *}$ & 1 & & & \\
OP & $0.742^{* *}$ & $0.621^{* *}$ & 1 & 1 & \\
ICEP & $0.271^{* *}$ & $0.404^{* *}$ & $0.333^{* *}$ & $0.418^{* *}$ & 1 \\
SCVP & $0.551^{* *}$ & $0.763^{* *}$ & $0.633^{* *}$ & \\
\hline
\end{tabular}

Note 1. ${ }^{* *} p<0.01 ;{ }^{* *}$ Correlational relationships are significant, ${ }^{* *} p<0.01 ;(2$-tailed). The correlational value of ICEP is somehow less than 0.70 threshold's level. However, it is greater than 0.70 , in the outer loading. Thus, ICEP must present its value in the model.

Table 7 presents a Multicollinearity assessment of SCVP, Env-per, ICEP, NPD, and OP. According to Hair et al., the variance influence factor must be less than 0.20 , and it should not be higher than 0.5 [126,131]. In our model, we have both formative and reflective approaches; thus, in the formative constructs, we should check the outer variance inflation factor VIF values [126,131].

Table 7. Shows a multicollinearity assessment (outer values) of CVP, Env-per, ICEP, NPD, and OP.

\begin{tabular}{cc}
\hline Variables & Outer Values \\
\hline SCVP & 2.66 \\
Env-per & 2.306 \\
ICEP & 1.242 \\
NPD & 2.822 \\
OP & 2.879 \\
\hline
\end{tabular}

\subsection{Inner Structural Model's Evaluation through Smart-PLS.}

In this study, we evaluated and confirmed the validity scores and reliability values of the measurement model. The next stage in the evaluation process describes how to calculate inner structural model outcomes.

Table 8 presents a Multicollinearity assessment between CSR = corporate social responsibility, $\mathrm{SCVP}=$ superior customer value performance, Env-per $=$ environmental performance, ICEP $=$ 
information capital effective performance, $\mathrm{NPD}=$ new product development, $\mathrm{OP}=$ organizational performance, and SMTU = social media marketing application.

Table 8. Multicollinearity assessment (inner values) CSR, SCVP, Env-per, ICEP, NPD, OP, and SMTU.

\begin{tabular}{cccccccc}
\hline Variables & CSR & SCVP & Env-per & ICEP & NPD & OP & SMTU \\
\hline CSR & & 2.164 & 2.331 & 2.365 & 2.411 & 2.536 & 1 \\
SCVP & & & 1.52 & 1.726 & 1.871 & 2.541 & \\
Env-per & & & & 1.363 & 1.367 & 1.506 & \\
ICEP & & & & & 1.256 & 1.284 & \\
NPD & & & & & & 3.452 & \\
OP & & & 1.751 & 1.742 & 1.397 & & \\
SMTU & & 2.164 & 2.298 & 2.432 & 2.523 & 2.613 & \\
\hline
\end{tabular}

\subsection{Calculating $\left(R^{2}\right)$ Value}

Coefficients of determination calculate the variance, and the overall effect size is illustrated in the endogenous constructs for the structural model by calculating the predictive accuracy of the model. The inner-path model's value indicated is at 0.550 for the sustainable performance endogenous latent-construct. It also shows that these constructs of the model significantly explain $55.00 \%$ of the variance regarding corporate social responsibility. The results suggest that the model's independent variables caused $55.00 \%$ of the change in the sustainable performance of a firm. In studies by Hair et al. [126,131], and Henseler et al. [131], $R^{2}$ was considered to be substantial at a value of 0.75 , moderate at 0.50 , and weak at 0.26 . In this study, a significant value of $R^{2}$ of 0.55 was obtained.

\subsection{Path Coefficients and $t$-Value Estimation}

We tested the significance of the proposed hypothesis by calculating the standardized beta $(\beta)$ value. The value of beta $(\beta)$ describes a probable variation of the constructs of the dependent variable in a study for unit-variation in the constructs of the independent variable. We calculated the beta $(\beta)$ value for each path in this hypothesized model. There will be higher and significant substantial effects on the constructs of endogenous-latent variable if the beta $(\beta)$ values are also higher and significant. The $t$-test is a technique to verify the significance level of the beta $(\beta)$ value. In this study, we used a bootstrapping method to evaluate and assess the significance of the proposed hypothesis [126].

\subsection{Moderation Analysis}

In moderation analysis, we used the two stages approach, as Hair et al., Ringle, and Sarstedt recommended this method for thoroughly measuring the exogenous construct (an informative way) $[126,131]$. We calculated the "reliability" and validity of social media marketing application as a moderator in this model. First, we examined its direct and significant effects without involving a moderator. Figure 5 indicates the immediate and considerable impact of corporate social responsibility as independent variable (IV), social media marketing application (Moderating variable), and small firms' sustainable performance is the dependent variable (DV). 


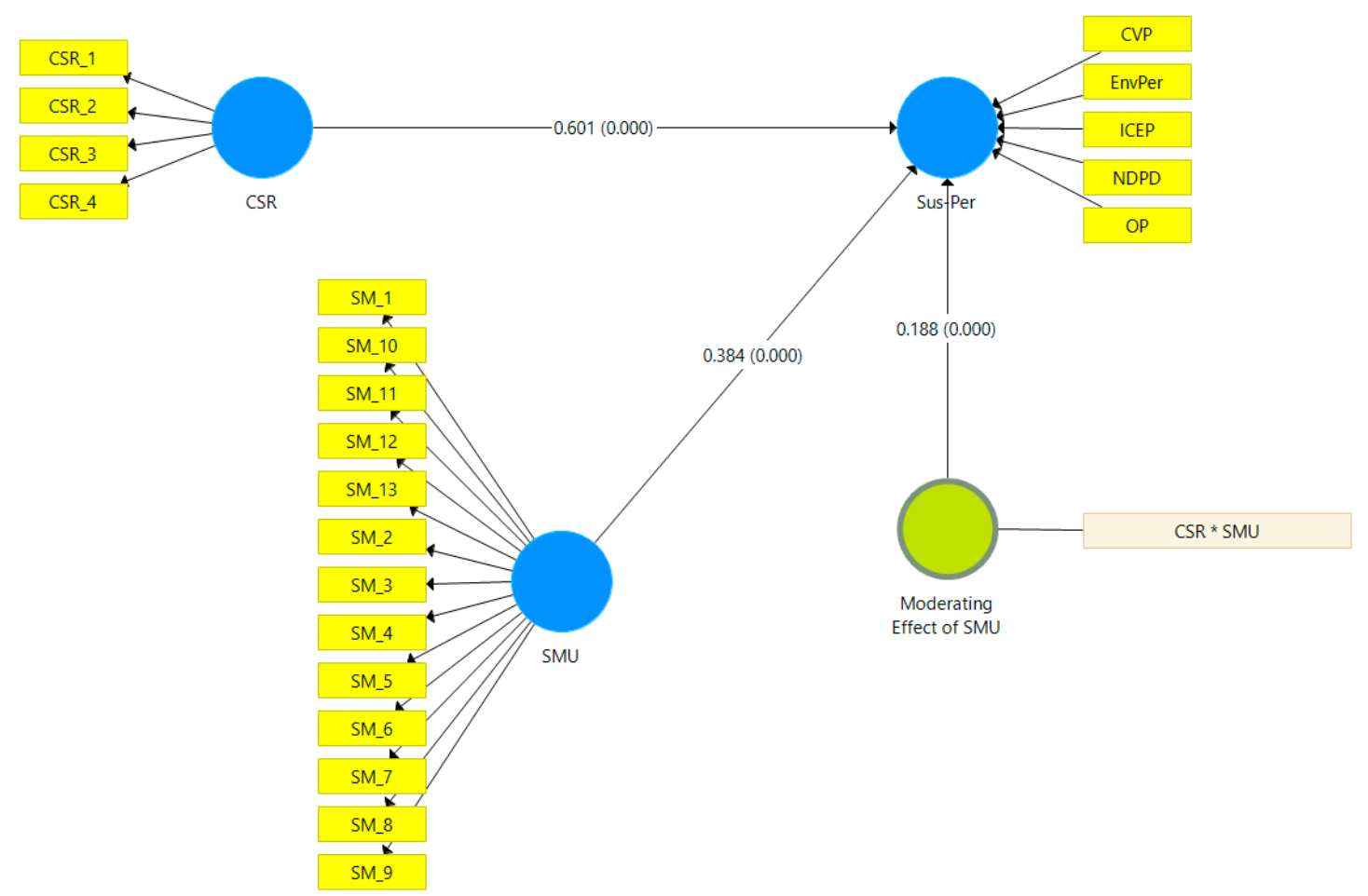

Figure 5. Describes the effects of moderation analysis for hypotheses resting (See Table 9).

Table 9 presents the analysis of the structural model of the proposed framework of the study. The results of $\mathrm{H} 1$ indicate that corporate social responsibility reveals a significant positive influence on the sustainable performance of business firms/SMEs, and, statistically, it reveals significance at the $5 \%$ level ( $\beta=0.602, t=3.57, p=0.000$ ). Thus, the results support $\mathrm{H} 1$, which claimed, "There is a positive and significant relationship between corporate social responsibility and firms' sustainable performance." Hypothesis 2 stated, "Social media marketing application moderates the association between corporate social responsibility and firms' sustainable performance." Thus, the results of Table 9 endorse the significant positive relationships $(\beta=0.188, t=6.175, p<0.000)$ and affirm H2. As a final point, Hypothesis 3 stated, "There is a significant positive effect of social media marketing application on firms' sustainable performance." The applications of social media marketing tools significantly and positively influence the sustainable performance of a firm, and the findings of this study support $\mathrm{H} 3$, as indicated in Table $9(\beta=0.384, t=9.802, p<0.000)$. See Figure 6 and Table 9.

Table 9. Hypothesis testing.

\begin{tabular}{ccccc}
\hline Hypothesis Path & Standard Beta $(\boldsymbol{\beta})$ & $\boldsymbol{t}$-Values & $\boldsymbol{p}$-Values & Decision \\
\hline CSR $\rightarrow$ SUS-PER & 0.601 & $3.957^{* * *}$ & 0.000 & Supported \\
Moderating Effect & 0.188 & $6.175^{* * *}$ & 0.000 & Supported \\
$1 \rightarrow$ SUS-PER & 0.384 & $9.802^{* * *}$ & 0.000 & Supported \\
SMTU $\rightarrow$ SUS-PER &
\end{tabular}

Note. ${ }^{*}$ Specifies significant paths; ${ }^{*} p<0.05 ;{ }^{* *} p<0.01 ;{ }^{* * *} p<0.001$. 


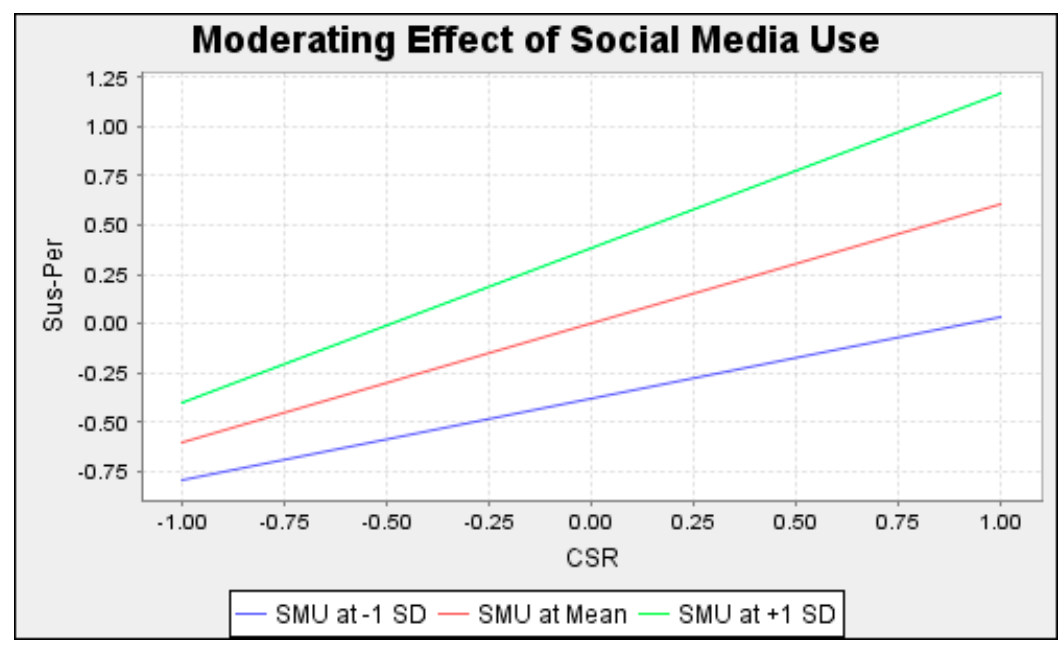

Figure 6. The moderating effect of social media marketing application on sustainable performance.

Measuring the Effect Size $\left(f^{2}\right)$

Concerning the effect sizes $\left(f^{2}\right)$ of the selected variables of this model, Cohen (2013) stated that $f^{2}=0.35$ presents a strong, $f^{2}=0.15$ reflects a moderate, and $f^{2}=0.02$ shows a weak effect between the variables [133]. Table 10 presents the effect size $\left(f^{2}\right)$ values measured by the smart-PLS-SEM approach. Table 10 shows that the findings of this study on $\left(f^{2}\right)$ present a satisfactory connection between corporate social responsibility and the sustainable performance of firms (a moderate effect of 0.228) through the moderating effect of the social media marketing application, as indicated in Table 10 below (see Figure 7).

Table 10. Effect size: Measuring the effect size $\left(f^{2}\right)$.

\begin{tabular}{ccc}
\hline Exogenous Latent Variables & $\left(\boldsymbol{f}^{\mathbf{2}}\right)$ & Effect Size. \\
\hline CSR $\rightarrow$ firm sustainable performance & 0.228 & Moderate effect \\
Moderating Effect of SMTU & 0.161 & Moderate effect \\
SMTU $\rightarrow$ firm sustainable performace & 0.152 & Moderate effect \\
\hline
\end{tabular}

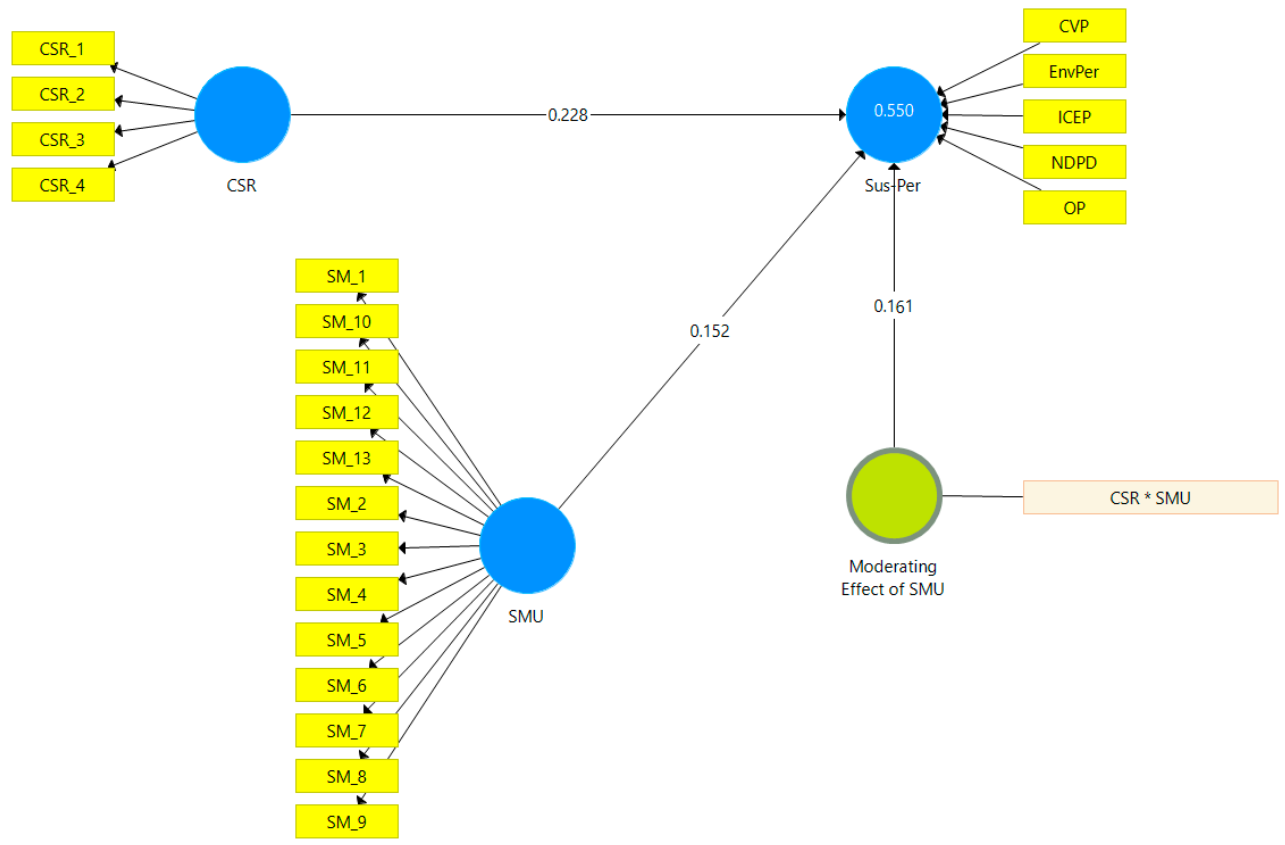

Figure 7. Shows Effect Size $\left(f^{2}\right)$ Measurement. 


\subsection{Model's Predictive-Relevance $\left(Q^{2}\right)$}

The predictive-relevance method evaluates/assesses the smart-PLS path model's quality, and is estimated by using the procedure of blindfolding [134]. In this proposed model, we performed cross-validated redundancy. The predictive relevance model $\left(\mathrm{Q}^{2}\right)$ recommends that the projected model should predict the model's endogenous latent constructs. The predictive-relevance $\left(\mathrm{Q}^{2}\right)$ values calculated in smart-PLS-SEM $(>0)$ must be higher than zero for the explicit endogenous-latent constructs (see Figure 8).

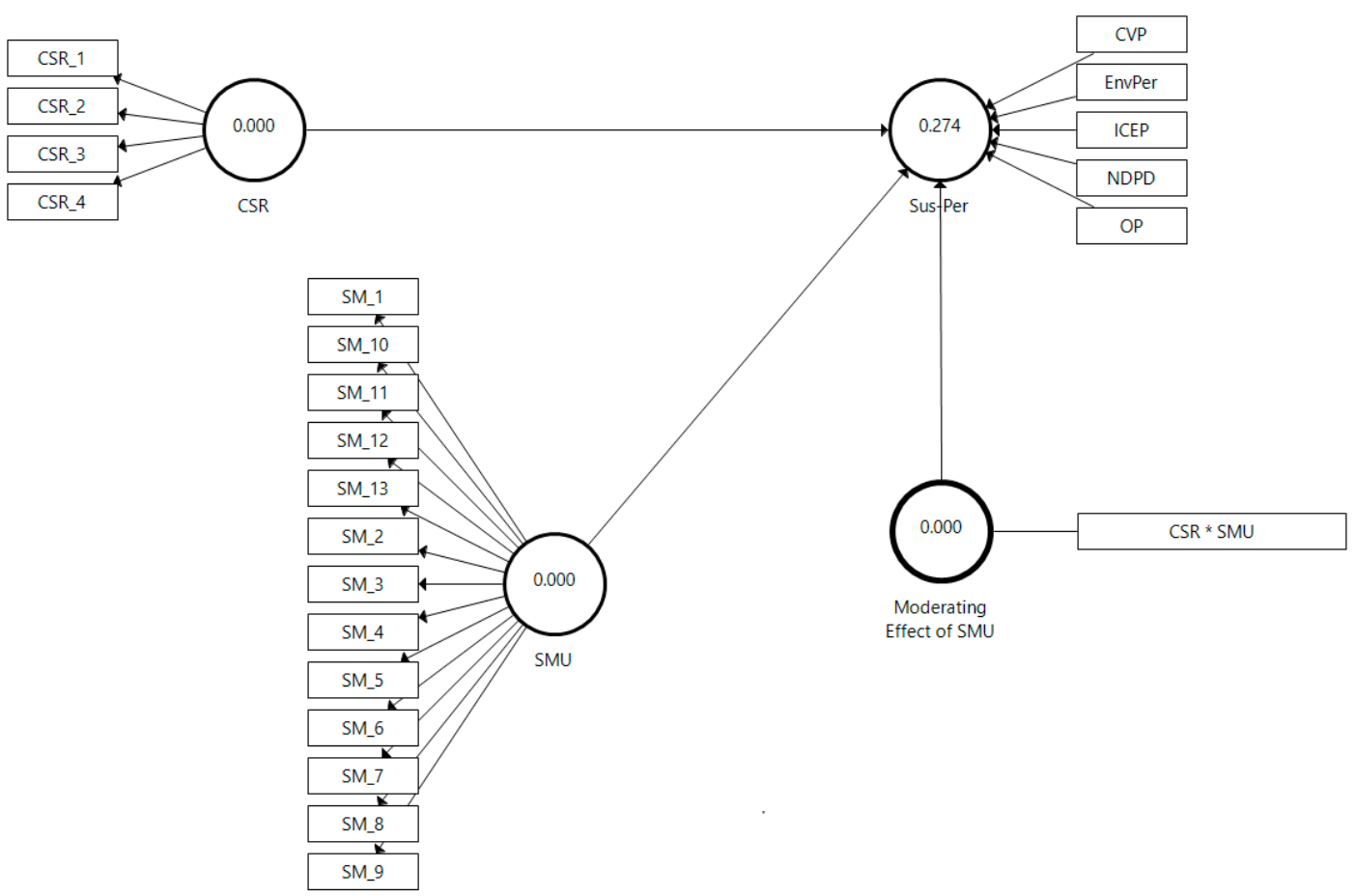

Figure 8. The predictive-relevance $\left(\mathrm{Q}^{2}\right)$ of the study model.

Figure 8 demonstrates the predictive relevance $\left(Q^{2}\right)$ for this particular model and shows its value as 0.274 , which is higher than its threshold limit. These results support the predictive relevance of the path model, which is suitable for the endogenous constructs.

\subsection{The Standardized-Root-Mean-Square-Residual (SRMR)}

The standardized-root-mean-square-residual (SRMR) is an average index of the standardized-residuals between hypothesized and observed covariance-matrices [135]. It is the measurement of a projected and projected proposed model's fit [136]. If the SRMR value is equal or less than 0.08 , it indicates satisfactory performance, a good fit, and that the study model is acceptable. The results show an SRMR value of 0.071, which is a good fit for the model, as shown in Table 11. The chi-square $\left(\chi^{2}\right)$ value is 2058.48 , and Normed fit index (NFI) shows the value of 0.768 , as shown in Table 11 [137].

Table 11. The summary of model-fit.

\begin{tabular}{cc}
\hline & Estimated-Model \\
\hline SRMR & 0.071 \\
d-ULS & 1.267 \\
d-G & 0.739 \\
Chi-square $\left(\chi^{2}\right)$ & 2058.48 \\
NFI & 0.768 \\
\hline
\end{tabular}




\section{Discussion}

The conclusions of this precise study quantified the practices of corporate social responsibility and are useful for business firms in enhancing sales growth and social good, as customers prefer to purchase the products or services of the companies which are socially responsible; these customers critically contribute to firms' enhanced performance. The results of this model show that there is a significant positive relationship between CSR practices and firms' sustainable performance. This study focused on examining how social media marketing application moderates the relationship between the sustainable performance of business firms and corporate social responsibility practices. A key emphasis of this study exploring the effect of marketing factors, including social media marketing, new product development, superior customer value performance, information capital effective performance, superior-customer-value-performance, the international and environmental performance of business firms, and corporate social performance, to attain customer satisfaction. The adaption of social media generates an extensive network among business organizations, customers, suppliers, retailers, and other stakeholders [109], and it plays a critical role in building long-term business relationships with consumers, suppliers, retailers, and other stakeholders. It implies that business firms should consider using social media marketing networks to approach their consumers, suppliers, retailers, and other stakeholders for the determination of building long-term relationships in the competitive business environment, which, in response, could enhance sustainable performance. The findings indicate that social media marketing significantly influences customers' satisfaction, which, in turn, increases a firm's sales volumes, adds to its profitability, and develops sustainable performance [43,119,138-140]. At present, customers use social media application frequently in the digital age. Therefore, social media marketing offers a beneficial and useful platform for business firms to share information with clienteles, such as discounts that are more attractive, new offers, and exclusive coupons. Social media marketing application supports firms' ability to keep in touch with their consumers, suppliers, and retailers for offering superior value-performance in comparison to other competitors. The findings of this specific study also indicate that strategies of social media marketing significantly affect customers' satisfaction, and these results show consistency with past studies [43,138,141-143].

This precise study applied the smart-PLS-SEM technique by performing a comprehensive analysis for evaluating and assessing the structural and measurement models, and the study results approved the validity of these models. This model implemented the advanced tools of the smart-PLS-SEM software-3.2.8 and applied a multivariate analysis technique for assessing and evaluating models that have variance-based structural equations [49]. The predictive relevance $\left(Q^{2}\right)$ for this particular model was satisfactory and revealed a value of 0.274 , which is higher than its threshold limit. These results support the path model's validity through predictive-relevance, which is suitable for endogenous constructs. Therefore, these results approve the credibility of the path model of this particular survey, which presented a satisfactory outcome for the endogenous constructs. It also suggests that the model holds predictive-relevance $\left(\mathrm{Q}^{2}\right)$. In direct relation to CSR practices and the sustainable performance of firms, the $R$-square $\left(R^{2}\right)$ was 0.55 . When adding social media marketing application as the moderating variable, the sustainable performance of firms increased. Hair Jr. et al. (2016) stated that the R-square value $\left(R^{2}\right)$ value ranged between -1 and +1 When $R^{2}$ is near 1 - either positive or negative and achieving a significant level-it will show a strong relationship [126,131]. Table 9 presents the analysis of the structural model of this proposed framework of the study. The results of $\mathrm{H} 1$ indicate that CSR practices reveal a significant positive influence on the sustainable performance of business firms/SMEs, and, statistically, it reveals significance at the $5 \%$ level $(\beta=0.602, t=3.57, p=0.000)$. Thus, the results support H1, which claimed: "There is a significant positive relationship between corporate social responsibility and firms' sustainable performance." Hypothesis 2 stated that "Social media marketing application moderates the association between the practices of corporate social responsibility and business firms' sustainable performance." The results in Table 9 endorse the significant positive relationships ( $\beta=0.188, t=6.175, p<0.000$ ) and approve H2. As a final point, Hypothesis 3 stated that "There is a significant positive effect of social media marketing application on firms' sustainable 
performance." The applications of social media marketing application significantly and positively influence the sustainable performance of firms, and the findings of this study support $\mathrm{H} 3$, as indicated in Table $9(\beta=0.384, t=9.802, p<0.000)$.

Jensen and Jepsen (2006 stated that offering various marketing promotional campaigns creates primary sources of indirect or direct marketing activities, which develop excellent advantageous opportunities for consumers to select their desired products and services comfortably. Firms might use a social media marketing platform to offer a price promotion, as it is in the best interest of a business firm to attract customers and retailers to increase sales performance, which ultimately enhances their profitability and capacity for sustainable production. Previous studies revealed that existing consumers feel satisfied and rewarded, and they appreciate the superior-value offerings of receiving better price discounts. The advantages of special discounts, prominent offers, and price promotions enhance customer loyalty. It is a successful central strategy of a firm to maintain favorable long-term business relationships with clienteles, suppliers, retailers, and other stakeholders. Social media marketing application supports business firms in enhancing sustainable international marketing [41], reductions in processes costs, efficiency in decision-making, revenue generation [42], and the refining of innovative business processes [43]. They also help to reduce the cost of marketing campaigns, enhance customers relationships, and create a competitive position [44]. Moen, Aspelund, and Koed Madsen (2008) specified that a business firm typically utilizes social media marketing platforms to improve market performance. Information and communication technologies (ICT) assist a business firm in enhancing global business-to-business marketing activities [46]. Shuai and $\mathrm{Wu}$ (2011) identified the ideas that internet marketing activity might influence a firm's operating performance, and utilizing the internet can be a more strategic technique to increase profitability and growth [48]. Many researchers have investigated eco-innovation and proactive environmental strategy as sources of competitive benefit [92,93]; however, few studies have examined how eco-innovation and a proactive environmental approach encourage a firm's dynamic capabilities [94]. This research addresses the gap between the relationship between environmental effects and firms' sustainable performance. Market-oriented business firms highly prioritize clienteles by offering them superior customer value [51]. Usually, business firms contend that possessing a market-orientation is imperative and that it is not enough to merely produce and offer customers superior value. As an alternative, business firms can attract clienteles by building knowledge about their consumers, and these firms should serve their consumers better by providing more excellent value [54].

Past literature has indicated that B2B salespeople's moral climate perceptions affect their perceived relationships with their sales supervisors and commitments to offering superior customer value $[60,61]$. Business firms emphasize the understanding and provision of customer value under the impression that this focus helps enhance firm sales, profitability, and sustainable performance [62-64]. Manufacturers could leverage new product development activities to increase product profitability and market share. Dwyer and Mellor (1991) stated that five indicators typically evaluate new product development: An overall assessment of a global success or failure probability, innovation in design and other aspects, marketability, sales opportunity, and profitability [80]. Lv and Zhang (2015) gave their indicators to evaluate NPD performance: The investment for growth rate, the ratio of investments, the sales ratio, the sales growth rate, the market share, and the ratio of market growth [81]. The findings are insightful and provide valuable information on how business firms develop new products and how they measure the performance of NPD in the context of their anticipated profits and competitiveness with other products in the market [144]. When business firms implement the practices of CSR, they create a significant positive effect on customer satisfaction; our results confirmed that the practices of CSR play a central role in enhancing and establishing consumer comfort, which in turn enhances firms' sales volumes, profitability, and sustainable performance. Earlier studies identified the positive effects of internet use and technological tools to improve CSR practices [40]. Previous studies have indicated more excellent support on this concept and have reported that practicing CSR had a significant effect on customer satisfaction $[12,49,139,141,144]$. In general, CSR practices appear through business firms' 
commitment to considering the welfare of society by contributing to the culture and other social systems $[98,99]$. It is imperative to consider being socially responsible by offering a contribution to communities rather than being just profit-oriented; examples include protecting the environment and helping to resolve social problems. Firms might express these beneficial activities by adhering to ethical standards and policies. Previously, theoretical and empirical studies identified that firms being socially responsible are perceived positively by customers, and their behavior directly or indirectly influences buying decisions.

The practices of CSR significantly affect customers' satisfaction [100]. Luo and Bhattacharya (2006) identified that the practices of CSR and its implementation directly impacts customer satisfaction [101]. Additionally, investing in the methods of CSR is a foundation of competitive benefit because it enhances financial performance [102]. The findings of this survey revealed that practicing CSR is critical to succeeding in a very challenging and competitive business environment, and firms should put a higher emphasis on implementing the programs of social responsibility in favor of employees, customers, and suppliers. Also, such implementations should contribute to society at large. The findings of this study add to the existing body of literature about both CSR and social media marketing application as a platform to attract customers to increase sales volumes, which, in turn, enhances sustainable performance. According to the best of our knowledge, it is the first study with this model in a Pakistani context. This study concludes with the findings, practice, and shared potential directions for future research.

\section{Conclusions}

Corporate social responsibility practices create a substantial influence on firms' performance. This study explored how social media marketing application moderated the relationship between CSR and firms' sustainable performance. This precise study applied the smart-PLS-SEM technique by performing a comprehensive analysis of a structural model and a measurement model, and the study results approve the validity of these models. This model implemented the advanced tools of the smart-PLS-SEM software-3.2.8, a commonly applied multivariate analysis technique for assessing and evaluating models that have variance-based structural equations [49]. It is a useful approach for simultaneously testing the relationships of a proposed model's latent variable and manifest variables. This study applied this method because of the measurement and evaluation ability of the psychometric properties of the study's latent constructs. It determined which the most significant construct was and how this construct influences the sustainable performance of business firms. In direct relation to CSR practices and sustainable performance of firms, the R-square $\left(R^{2}\right)$ was 0.55 . When adding social media marketing application as the moderating variable, the sustainable performance of firms increased. Hair Jr et al. (2016) stated that the R-square value $\left(R^{2}\right)$ value should range between -1 and 1 . When the $R^{2}$ value is near 1 - either positive or negative and achieving a significant level—it will show a healthy relationship [127,132].

Results of the structural model of $\mathrm{H} 1$ indicated that CSR practices reveal a significant positive influence on the sustainable performance of business firms and SMEs. Statistically, it indicates significance at the $5 \%$ level $(\beta=0.602, t=3.57, p=0.000)$, and our results support H1, which claimed that "There is a significant positive relationship between CSR practices and firms' sustainable performance." Hypothesis 2 stated that "Social media marketing application moderates the relationship between the practices of CSR and firms' sustainable performance." The results in Table 9 also endorse the significant positive relationships ( $\beta=0.188, t=6.175, p<0.000$ ). Hypothesis 3 stated that "There is a significant positive effect of social media marketing application on firms' sustainable performance." The applications of social media marketing application significantly and positively affect the sustainable performance of firms, and the findings support H3, as indicated in Table 9 ( $\beta=0.384, t=9.802$, $p<0.000)$.

In recent years, business firms have had an excellent and incredible channel via the application of social media marketing in communicating with their consumers. Other communication and 
correspondence channels frequently surround social media, and supervisors are not attentive to how to utilize the interactive applications of social media marketing [145]. Social media marketing is particularly suitable and appropriate for reciprocal or two-way communication, correspondence, and the enabling and assistance of the interaction or dealings between customers and consumers. For organizations and business firms, this may mean that customer and other stakeholder interaction and communication might be carried out via social media marketing [146]. The use of social media marketing could be vital, and not only for business firms, to halt a decline in customer, stakeholder, company, and community trust [147]. Social media marketing has rapidly emerged and increased during the past decade, and, in response, various scholars of social media marketing (SMM) and organizations have increased their interest in SMM worldwide [148]. The findings of this study confirm all the hypothesized statements, and its results approve its proposed hypotheses. This precise research study offers an original method to determine and analyze the incorporated key constructs of the sustainable performance of business firms and the practices of CSR. The critical contribution of this research study, from a theoretical viewpoint, is the analysis of the respondents and their understanding of the practices of CSR, which, in turn, could help business firms to attain sustainable performance. The predictive relevance $\left(Q^{2}\right)$ for this particular model of the study was satisfactory and revealed a value of 0.274 , which is higher than its threshold limit [149]. These results support the path model's credibility through predictive-relevance results, which are suitable for the endogenous-constructs. Therefore, the path model's reliability of this particular survey was approved, which presents a satisfactory outcome of the endogenous constructs and suggests that the model holds predictive-relevance $\left(\mathrm{Q}^{2}\right)$. This prospective study finds that the use of social media applications plays a significant positive moderation between CSR and firm performance [150]. The study results provide numerous contributions to the existing literature, as well as managerial insights into the efficacy of social media marketing application. This study also contributes to the research of CSR practices and business firms' performance by giving answers to the call to increase the generalizability of the relationships between the practicing CSR, applications of a social media marketing application, and business firms' sustainable performance. The model contributes to the idea that CSR events typically lead to a favorable perception of social media marketing application as moderators between CSR and firm performance.

\subsection{Limitations and Recommendations}

Despite the remarkable contributions presented in this specific research study regarding the causal impacts of social media marketing, superior customer value, new product development, organizational performance, firms' internal and external environmental effects, and corporate social responsibility for sustainable production, this study also has some limits. Researchers might address these limitations in future studies to achieve different results. This study incorporated three factors: CSR, social media marketing application, and the sustainable performance of a firm. This study examined the effects of this proposed model by incorporating these three elements. Therefore, future studies might focus on other critical factors such as social norms, cultural factors, the dynamic capabilities of a firm, and an improved CSR strategy with larger sample size. The data received in this study were a cross-sectional survey in nature from telecom and manufacturing firms listed with the Multan Chamber of Commerce and Industries, Pakistan. It is recommended that future researchers adopt qualitative methodologies and that they expand the sample of their study to other areas and countries to enhance the generalizability of their findings.

\subsection{Implications}

The results of this research have enhanced the theoretical basis of explaining the interplay of corporate social responsibility and social media marketing application, both of which impact the sustainable performance of firms. These results have contributed to the existing body of scientific knowledge through the developing, testing, and refining of CSR and a sustainable performance model. This model explained $55 \%$ of the variance in a social media marketing application for improved 
performance. Overall, this research expands the existing body of scientific knowledge from a CSR point of view to include the perspective of social media marketing as a factor supporting/generating sustainable performance. The proposed CSR and sustainable-performance model, constructs, and measurement approach might be applicable in different regions of Pakistan and other areas-especially other countries. The implications of these findings may provide significant advantages to more than just academic researchers, including other industries such as service practitioners, business planners, and managers.

Sharma (2011) recognized that proactive-environmental-strategies (PES) encourage and improve financial outcomes by refining processes efficiency [89]. Álvarez-Gil et al. (2001) identified the significant positive relationships between business firms' environmental management practices and their economic performance [90]. In an earlier study, Molina-Azorín (2009) identified highly proactive business firms which practice environmental strategies and, therefore, attained and improved operational and financial performances [91]. Thus, environmental activities encourage firms to identify new business opportunities so that they can increase business, growth, profitability, and sustainable production. In short, exploration activities will benefit business firms in unstable environments. The existing literature on the activities of environmental management practices recognizes that firms' strategies on proactive ecological management and eco-innovation are known as business firms' dynamic capabilities which stimulate firms' competitive and challenging advantages; however, other organizational capabilities are also critical [151,152].

The outcomes of the study contribute to the existing body of the literature related to the practices of CSR and business firms' performance research in numerous ways. Unlike most of the previous studies that explained the impact of CSR practices and their relationships with enhanced performance of firms, this study primarily investigates the effect of CSR practices as an independent variable and its effects on the sustainable production of business firms (the dependent variable) $[153,154]$. This study introduces three variables - namely CSR, the sustainable-performance of business firms, and the application of social media marketing (the mediating variable). The CSR practices provide an alternative explanation for the deviating outcomes gained from past studies [155]. Corporate social responsibility improves the interaction relationship between business competitors, relationship resources, the power of firm resource control, cohesion, and trust coming from the communication and interaction between business industries and other members in the business network. Members of business networks can exchange knowledge, share resources, and complement capabilities through business networks $[156,157]$. This outcome is also in line with the explanations of Tseng and Lee (2014), Mahmood (2015), and Lin and $\mathrm{Wu}$ (2014), as these studies stated that dynamic capabilities positively influenced the relationship between firms' valuable resources and their enhanced performance [158-161].

Figure 2 indicates that corporate social responsibility has a direct effect on firms' sustainable performance, which provides feedback on CSR activities choices. However, Figure 2 also shows a more complex set of connections among available business opportunities, learning processes, relationship building, developing capabilities, and organizational outcomes. The main feature of this research model is to examine the effects of CSR practices on the sustainable performance of business firms through the moderating role of a social media marketing application. This model indicates that the nature and quality of social media marketing application refine business firms' enhanced performance. A firm's knowledge stems from available organizational resources and the learning process the venture implements early on. When it comes to developing and exploiting available capabilities, new product development, environmental effects, and superior customer vales performances aid existing firms, and new ventures might have various types of advantages [162]. However, previous literature has poorly cataloged these differences. Future studies can enrich our highlighted understanding of these problems. These understandings might assist us in forming multiple prescriptions for the established relationship between the practices of CSR and the sustainable performance of business firms $[163,164]$.

Author Contributions: J.A. (Jaffar Abbas) has conceptualized the idea, completed Introduction, Literature, Methodology, Discussion, Conclusion and edited the original manuscript, S.M. method section, H.A. data process, 
M.A.R. data \& analysis, G.A. reviewed, J.A. (Jaffar Aman), and S.B. provided resources. G.A. and M.N. reviewed the edited manuscript.

Funding: The authors received no funding for this project for conducting research, the rigorous process of data collection, and other associated costs for this study. The authors also acknowledge the support from the College of Management, Shenzhen University, Nanshan District, Shenzhen; Guangdong, China.

Acknowledgments: Special thanks to MDPI professional language editing services to ensure that English grammar is free of mistakes for this manuscript. Jinzu Ling and Li Ben-qian supervised this project.

Conflicts of Interest: The authors are well informed about the study's objectives, provided consent, and have declared that they have no competing interest.

\section{References}

1. Peloza, J.; Green, T. How does corporate social responsibility create value for consumers? J. Consum. Mark. 2011, 28, 48-56.

2. Famiyeh, S. Corporate social responsibility and firm's performance: Empirical evidence. Soc. Responsib. J. 2017, 13, 390-406. [CrossRef]

3. Moir, L. What do we mean by corporate social responsibility? Corp. Gov. Int. J. Bus. Soc. 2001, 1, 16-22. [CrossRef]

4. Branco, M.C.; Rodrigues, L.L. Corporate Social Responsibility and Resource-Based Perspectives. J. Bus. Ethics 2006, 69, 111-132. [CrossRef]

5. Ditlev-Simonsen, C.D. From corporate social responsibility awareness to action? Soc. Responsib. J. 2010, 6, 452-468. [CrossRef]

6. Tran, A.N.; Jeppesen, S. SMEs in their Own Right: The Views of Managers and Workers in Vietnamese Textiles, Garment, and Footwear Companies. J. Bus. Ethics 2016, 137, 589-608. [CrossRef]

7. Vives, A. Social and Environmental Responsibility in Small and Medium Enterprises in Latin America. J. Corp. Citizsh. 2006, 2006, 39-50. [CrossRef]

8. Williamson, D.; Lynch-Wood, G.; Ramsay, J. Drivers of Environmental Behaviour in Manufacturing SMEs and the Implications for CSR. J. Bus. Ethics 2006, 67, 317-330. [CrossRef]

9. Hodges, C. Law and Corporate Behaviour: Integrating Theories of Regulation, Enforcement, Compliance and Ethics; Bloomsbury Publishing: Oxford, UK, 2015.

10. Dobers, P.; Halme, M. Corporate social responsibility and developing countries. Corp. Soc. Responsib. Environ. Manag. 2009, 16, 237-249. [CrossRef]

11. Jamali, D. The Case for Strategic Corporate Social Responsibility in Developing Countries. Bus. Soc. Rev. 2007, 112, 1-27. [CrossRef]

12. Baughn, C.C.; Bodie, N.L.; McIntosh, J.C. Corporate social and environmental responsibility in Asian countries and other geographical regions. Corp. Soc. Responsib. Environ. Manag. 2007, 14, 189-205. [CrossRef]

13. Luken, R.A. Where is developing country industry in sustainable development planning? Sustain. Dev. 2006, 14, 46-61. [CrossRef]

14. StachowiczStanusch, A. Corporate Social Performance: Reflecting on the Past and Investing in the Future; Information Age Publishing Incorporated: Charlotte, NC, USA, 2016.

15. Hur, K.; Kim, T.T.; Karatepe, O.M.; Lee, G. An exploration of the factors influencing social media continuance usage and information sharing intentions among Korean travellers. Tour. Manag. 2017, 63, 170-178. [CrossRef]

16. Chen, Y.; Fay, S.; Wang, Q. The Role of Marketing in Social Media: How Online Consumer Reviews Evolve. J. Interact. Mark. 2011, 25, 85-94. [CrossRef]

17. Harrigan, P.; Evers, U.; Miles, M.; Daly, T. Customer engagement with tourism social media brands. Tour. Manag. 2017, 59, 597-609. [CrossRef]

18. Watson, J. Modeling the relationship between networking and firm performance. J. Bus. Ventur. 2007, 22, 852-874. [CrossRef]

19. Nisar, T.M.; Whitehead, C. Brand interactions and social media: Enhancing user loyalty through social networking sites. Comput. Hum. Behav. 2016, 62, 743-753. [CrossRef]

20. Kaplan, A.M. Social Media, the Digital Revolution, and the Business of Media. Int. J. Media Manag. 2015, 17, 197-199. [CrossRef] 
21. Malthouse, E.C.; Haenlein, M.; Skiera, B.; Wege, E.; Zhang, M. Managing Customer Relationships in the Social Media Era: Introducing the Social CRM House. J. Interact. Mark. 2013, 27, 270-280. [CrossRef]

22. Mithas, S.; Ramasubbu, N.; Sambamurthy, V. How Information Management Capability Influences Firm Performance. MIS Q. 2011, 35, 237-256. [CrossRef]

23. Lahiri, S.; Kedia, B.L.; Mukherjee, D. The impact of management capability on the resource-performance linkage: Examining Indian outsourcing providers. J. World Bus. 2012, 47, 145-155. [CrossRef]

24. Nath, P.; Nachiappan, S.; Ramanathan, R. The impact of marketing capability, operations capability and diversification strategy on performance: A resource-based view. Ind. Mark. Manag. 2010, 39, 317-329. [CrossRef]

25. Rapp, A.; Trainor, K.J.; Agnihotri, R. Performance implications of customer-linking capabilities: Examining the complementary role of customer orientation and CRM technology. J. Bus. Res. 2010, 63, 1229-1236. [CrossRef]

26. Morgan, N.A.; Vorhies, D.W.; Mason, C.H. Market orientation, marketing capabilities, and firm performance. Strateg. Manag. J. 2009, 30, 909-920. [CrossRef]

27. Srinivasan, R.; Moorman, C. Strategic Firm Commitments and Rewards for Customer Relationship Management in Online Retailing. J. Mark. 2005, 69, 193-200. [CrossRef]

28. Silvius, G. Strategic Integration of Social Media into Project Management Practice; IGI Global: Hershey, PA, USA, 2016.

29. Kaplan, A.M.; Haenlein, M. Users of the world, unite! The challenges and opportunities of Social Media. Bus. Horiz. 2010, 53, 59-68. [CrossRef]

30. Minai, M.S.; Ibrahim, Y.; Kheng, L.K. Entrepreneurial network in Malaysia: Are there any differences across ethnic groups? J. Bus. Policy Res. 2012, 7, 178-192.

31. Kregar, T.B.; Antoncic, B. Entrepreneurial Networks: The Multiplexity of Exchange Content. In Economic and Social Development: Book of Proceedings, 8th International Scientific Conference on Economic and Social Development and 4th Eastern European ESD Conference; Building Resilient Economy: Zagreb, Croatia, 2014.

32. Parker, S.C. The Economics of Entrepreneurship; Cambridge University Press: Cambridge, UK, 2018.

33. Abbas, J.; Raza, S.; Nurunnabi, M.; Minai, M.S.; Bano, S. The Impact of Entrepreneurial Business Networks on Firms' Performance Through a Mediating Role of Dynamic Capabilities. Sustainability 2019, 11, 3006. [CrossRef]

34. Irwansyah, E. Geographic Information System (GIS) Using IDRISI Software: Application in Coastal Management; Geoinforma: Depok, Indonesia, 2012.

35. Asghari, F.B.; Mohammadi, A.A.; Dehghani, M.H.; Yousefi, M. Data on assessment of groundwater quality with application of ArcGIS in Zanjan, Iran. Data Brief 2018, 18, 375-379. [CrossRef]

36. Cowling, M.; Liu, W.; Ledger, A.; Zhang, N. What really happens to small and medium-sized enterprises in a global economic recession? UK evidence on sales and job dynamics. Int. Small Bus. J. 2014, 33, 488-513. [CrossRef]

37. Gaganis, C.; Pasiouras, F.; Voulgari, F. Culture, business environment and SMEs' profitability: Evidence from European Countries. Econ. Model. 2019, 78, 275-292. [CrossRef]

38. Huang, H.-C.; Lai, M.-C.; Lo, K.-W. Do founders' own resources matter? The influence of business networks on start-up innovation and performance. Technovation 2012, 32, 316-327. [CrossRef]

39. Law, K.K. Firm Performance and Entrepreneurial Network: The Moderating Effect of Resources Factor in a Multiracial Country. Ph.D. Thesis, Universiti Utara Malaysia, Sintok, Malaysia, 2012.

40. O'Leary, C.; Perry, C.; Rao, S. Improving customer relationship management through database/Internet marketing: A theory-building action research project. Eur. J. Mark. 2004, 38, 338-354. [CrossRef]

41. Nhat Lu, V.; Julian, C.C. The internet and export marketing performance: The empirical link in export market ventures. Asia Pac. J. Mark. Logist. 2007, 19, 127-144. [CrossRef]

42. Teo, T.S.H.; Choo, W.Y. Assessing the impact of using the Internet for competitive intelligence. Inf. Manag. 2001, 39, 67-83. [CrossRef]

43. Parveen, F.; Jaafar, N.I.; Ainin, S. Social media's impact on organizational performance and entrepreneurial orientation in organizations. Manag. Decis. 2016, 54, 2208-2234. [CrossRef]

44. Molla, A.; Heeks, R. Exploring E-Commerce Benefits for Businesses in a Developing Country. Inf. Soc. 2007, 23, 95-108. [CrossRef]

45. Swierczek, F.W.; Thi Phuong Thao, H. Internet use, customer relationships and loyalty in the Vietnamese travel industry. Asia Pac. J. Mark. Logist. 2008, 20, 190-210. 
46. Moen, Ø.; Aspelund, A.; Koed Madsen, T. The importance of the internet in international business-to-business markets. Int. Mark. Rev. 2008, 25, 487-503. [CrossRef]

47. Parveen, F.; Jaafar, N.I.; Ainin, S. Social media usage and organizational performance: Reflections of Malaysian social media managers. Telemat. Inform. 2015, 32, 67-78. [CrossRef]

48. Shuai, J.-J.; Wu, W.-W. Evaluating the influence of E-marketing on hotel performance by DEA and grey entropy. Expert Syst. Appl. 2011, 38, 8763-8769. [CrossRef]

49. Pérez, A.; Rodríguez del Bosque, I. Corporate social responsibility and customer loyalty: Exploring the role of identification, satisfaction and type of company. J. Serv. Mark. 2015, 29, 15-25. [CrossRef]

50. Rodriguez, M.; Peterson, R.M.; Ajjan, H. Crm/Social Media Technology: Impact on Customer Orientation Process and Organizational Sales Performance. In Ideas in Marketing: Finding the New and Polishing the Old; Springer International Publishing: Cham, Switzerland, 2015; pp. 636-638.

51. Slater, S.F.; Narver, J.C. Market-oriented is more than being customer-led. Strateg. Manag. J. 1999, 20, 1165-1168. [CrossRef]

52. Kohli, A.K.; Jaworski, B.J. Market Orientation: The Construct, Research Propositions, and Managerial Implications. J. Mark. 1990, 54, 1-18. [CrossRef]

53. Zhou, K.Z.; Li, J.J.; Zhou, N.; Su, C. Market orientation, job satisfaction, product quality, and firm performance: Evidence from China. Strateg. Manag. J. 2008, 29, 985-1000. [CrossRef]

54. Zhou, K.Z.; Yim, C.K.; Tse, D.K. The Effects of Strategic Orientations on Technology- and Market-Based Breakthrough Innovations. J. Mark. 2005, 69, 42-60. [CrossRef]

55. Farrell, M.A.; Oczkowski, E. Are Market Orientation and Learning Orientation Necessary for Superior Organizational Performance? J. Mark.-Focused Manag. 2002, 5, 197-217.

56. Raudszus, M.; Schiereck, D.; Trillig, J. Does vertical diversification create superior value? Evidence from the construction industry. Rev. Manag. Sci. 2014, 8, 293-325. [CrossRef]

57. Menguc, B.; Auh, S. Creating a firm-level dynamic capability through capitalizing on market orientation and innovativeness. J. Acad. Mark. Sci. 2006, 34, 63-73. [CrossRef]

58. Payne, A.; Frow, P. A Strategic Framework for Customer Relationship Management. J. Mark. 2005, 69, 167-176. [CrossRef]

59. Payne, A.; Frow, P.; Eggert, A. The customer value proposition: Evolution, development, and application in marketing. J. Acad. Mark. Sci. 2017, 45, 467-489. [CrossRef]

60. Value Merchants: Demonstrating and Documenting Superior Value in Business Markets. J. Serv. Manag. 2009, 20, 580-583.

61. Schwepker, C.H. Psychological ethical climate, leader-member exchange and commitment to superior customer value: Influencing salespeople's unethical intent and sales performance. J. Pers. Sell. Sales Manag. 2017, 37, 72-87. [CrossRef]

62. Lindgreen, A.; Wynstra, F. Value in business markets: What do we know? Where are we going? Ind. Mark. Manag. 2005, 34, 732-748. [CrossRef]

63. Ingram, T.N.; Schwepker, C.H. Ethical leadership in the salesforce: Effects on salesperson customer orientation, commitment to customer value and job stress. J. Bus. Ind. Mark. 2016, 31, 914-927.

64. Terho, H.; Haas, A.; Eggert, A.; Ulaga, W. 'It's almost like taking the sales out of selling'-Towards a conceptualization of value-based selling in business markets. Ind. Mark. Manag. 2012, 41, 174-185. [CrossRef]

65. Kahn, K.B. The PDMA Handbook of New Product Development; Wiley: Hoboken, NJ, USA, 2012.

66. Kaynak, E.; Mills, N.; Brooke, M.Z. New Product Development: Successful Innovation in the Marketplace; Taylor \& Francis: New York, NY, USA, 2012.

67. Annacchino, M. The Pursuit of New Product Development: The Business Development Process; Elsevier Science: Amsterdam, The Netherlands, 2011.

68. Cadeddu, S.B.M.; Donovan, J.D.; Topple, C.; de Waal, G.A.; Masli, E.K. Frugal Innovation and the New Product Development Process: Insights from Indonesia; Taylor \& Francis: London, UK, 2019.

69. Atuahene-Gima, K. Resolving the Capability-Rigidity Paradox in New Product Innovation. J. Mark. 2005, 69, 61-83. [CrossRef]

70. Szymanski, D.M.; Kroff, M.W.; Troy, L.C. Innovativeness and new product success: Insights from the cumulative evidence. J. Acad. Mark. Sci. 2007, 35, 35-52. [CrossRef] 
71. Charterina, J.; Basterretxea, I.; Landeta, J. Types of embedded ties in buyer-supplier relationships and their combined effects on innovation performance. J. Bus. Ind. Mark. 2016, 31, 152-163. [CrossRef]

72. Cheng, C.; Yang, M. Creative process engagement and new product performance: The role of new product development speed and leadership encouragement of creativity. J. Bus. Res. 2019, 99, 215-225. [CrossRef]

73. Calantone, R.J.; di Benedetto, C.A. An integrative model of the new product development process: An empirical validation. J. Prod. Innov. Manag. 1988, 5, 201-215. [CrossRef]

74. Arnett, D.B.; Sandvik, I.L.; Sandvik, K. Two paths to organizational effectiveness-Product advantage and life-cycle flexibility. J. Bus. Res. 2018, 84, 285-292. [CrossRef]

75. Goworek, H.; Oxborrow, L.; Claxton, S.; McLaren, A.; Cooper, T.; Hill, H. Managing sustainability in the fashion business: Challenges in product development for clothing longevity in the UK. J. Bus. Res. 2018, in press. [CrossRef]

76. Lukas, B.A.; Menon, A. New product quality: Intended and unintended consequences of new product development speed. J. Bus. Res. 2004, 57, 1258-1264. [CrossRef]

77. Bowersox, D.J.; Stank, T.P.; Daugherty, P.J. Lean Launch: Managing Product Introduction Risk Through Response-Based Logistics. J. Prod. Innov. Manag. 1999, 16, 557-568. [CrossRef]

78. Belvedere, V.; Cuttaia, F.; Rossi, M.; Stringhetti, L. Mapping wastes in complex projects for Lean Product Development. Int. J. Proj. Manag. 2019, 37, 410-424. [CrossRef]

79. Zhu, Q.; Shah, P.; Sarkis, J. Addition by subtraction: Integrating product deletion with lean and sustainable supply chain management. Int. J. Prod. Econ. 2018, 205, 201-214. [CrossRef]

80. Dwyer, L.; Mellor, R. New product process activities and project outcomes. RED Manag. 1991, $21,31-42$.

81. Lv, S.; Zhang, H. Effect of HR practice on NPD performance: The moderating role of environmental uncertainty. Nankai Bus. Rev. Int. 2015, 6, 256-280.

82. Milliken, F.J. Three Types of Perceived Uncertainty about the Environment: State, Effect, and Response Uncertainty. Acad. Manag. Rev. 1987, 12, 133-143. [CrossRef]

83. Daft, R.L. Organization Theory and Design; South-Western College Publishing: Cincinnati, OH, USA, 2001.

84. Sharfman, M.P.; Dean, J.W. Conceptualizing and Measuring the Organizational Environment: A Multidimensional Approach. J. Manag. 1991, 17, 681-700. [CrossRef]

85. Closs, D.J.; Jacobs, M.A.; Swink, M.; Webb, G.S. Toward a theory of competencies for the management of product complexity: Six case studies. J. Oper. Manag. 2008, 26, 590-610. [CrossRef]

86. Closs, D.J.; Nyaga, G.N.; Voss, M.D. The differential impact of product complexity, inventory level, and configuration capacity on unit and order fill rate performance. J. Oper. Manag. 2010, 28, 47-57. [CrossRef]

87. Ho, C.-F.; Tai, Y.-M.; Tai, Y.-M.; Chi, Y.-P. A Structural Approach to Measuring Uncertainty in Supply Chains. Int. J. Electron. Commer. 2005, 9, 91-114. [CrossRef]

88. Sitkin, S.B.; Sutcliffe, K.M.; Schroeder, R.G. Distinguishing Control From Learning In Total Quality Management: A Contingency Perspective. Acad. Manag. Rev. 1994, 19, 537-564. [CrossRef]

89. Sharma, A. Take-off of online marketing: Casting the next generation strategies. Bus. Strategy Ser. 2011, 12, 202-208. [CrossRef]

90. Álvarez Gil, M.J.; Burgos Jiménez, J.; Céspedes Lorente, J.J. An analysis of environmental management, organizational context and performance of Spanish hotels. Omega 2001, 29, 457-471. [CrossRef]

91. Molina-Azorín, J.F.; Claver-Cortés, E.; Pereira-Moliner, J.; Tarí, J.J. Environmental practices and firm performance: An empirical analysis in the Spanish hotel industry. J. Clean. Prod. 2009, 17, 516-524. [CrossRef]

92. Papadas, K.-K.; Avlonitis, G.J.; Carrigan, M.; Piha, L. The interplay of strategic and internal green marketing orientation on competitive advantage. J. Bus. Res. 2018, in press. [CrossRef]

93. Singjai, K.; Winata, L.; Kummer, T.-F. Green initiatives and their competitive advantage for the hotel industry in developing countries. Int. J. Hosp. Manag. 2018, 75, 131-143. [CrossRef]

94. Ryszko, A. Proactive Environmental Strategy, Technological Eco-Innovation and Firm Performance-Case of Poland. Sustainability 2016, 8, 156. [CrossRef]

95. McWilliams, A.; Siegel, D.S.; Wright, P.M. Corporate Social Responsibility: Strategic Implications. J. Manag. Stud. 2006, 43,1-18. [CrossRef]

96. Wood, D.J. Corporate Social Performance Revisited. Acad. Manag. Rev. 1991, 16, 691-718. [CrossRef]

97. Mohr, L.A.; Webb, D.J.; Harris, K.E. Do Consumers Expect Companies to be Socially Responsible? The Impact of Corporate Social Responsibility on Buying Behavior. J. Consum. Aff. 2001, 35, 45-72. [CrossRef] 
98. Matten, D.; Moon, J. Corporate Social Responsibility Education in Europe. J. Bus. Ethics 2004, 54, $323-337$. [CrossRef]

99. Smith, N.C. Corporate Social Responsibility: Whether or How? Calif. Manag. Rev. 2003, 45, 52-76. [CrossRef]

100. McDonald, L.M.; Rundle-Thiele, S. Corporate social responsibility and bank customer satisfaction: A research agenda. Int. J. Bank Mark. 2008, 26, 170-182. [CrossRef]

101. Luo, X.; Bhattacharya, C.B. Corporate Social Responsibility, Customer Satisfaction, and Market Value. J. Mark. 2006, 70, 1-18. [CrossRef]

102. Luo, X.; Zhang, J.; Duan, W. Social Media and Firm Equity Value. Inf. Syst. Res. 2012, 24, 146-163. [CrossRef]

103. Sfetcu, N. Web 2.0/Social Media/Social Networks; CreateSpace Independent Publishing Platform: Scotts Valley, CA, USA, 2017.

104. Hajli, M. A research framework for social commerce adoption. Inf. Manag. Comput. Secur. 2013, 21, $144-154$. [CrossRef]

105. Yonghwan, K.; Shih-Hsien, H.; Gil, D.Z.H. Influence of Social Media Use on Discussion Network Heterogeneity and Civic Engagement: The Moderating Role of Personality Traits. J. Commun. 2013, 63, 498-516.

106. Schaupp, L.C.; Bélanger, F. The Value of Social Media for Small Businesses. J. Inf. Syst. 2014, 28, $187-207$. [CrossRef]

107. Aichner, T.; Jacob, F. Measuring the Degree of Corporate Social Media Use. Int. J. Mark. Res. 2015, 57, 257-276. [CrossRef]

108. Barreda, A.A.; Bilgihan, A.; Nusair, K.; Okumus, F. Generating brand awareness in Online Social Networks. Comput. Hum. Behav. 2015, 50, 600-609. [CrossRef]

109. Michaelidou, N.; Siamagka, N.T.; Christodoulides, G. Usage, barriers and measurement of social media marketing: An exploratory investigation of small and medium B2B brands. Ind. Mark. Manag. 2011, 40, 1153-1159. [CrossRef]

110. Naudé, P.; Zaefarian, G.; Najafi Tavani, Z.; Neghabi, S.; Zaefarian, R. The influence of network effects on SME performance. Ind. Mark. Manag. 2014, 43, 630-641. [CrossRef]

111. Management Association, I.R. Social Media and Networking: Concepts, Methodologies, Tools, and Applications: Concepts, Methodologies, Tools, and Applications; IGI Global: Hershey, PA, USA, 2015.

112. Management Association, I.R. Technology Adoption and Social Issues: Concepts, Methodologies, Tools, and Applications: Concepts, Methodologies, Tools, and Applications; IGI Global: Hershey, PA, USA, 2015.

113. Harrington, R.J.; Ottenbacher, M.C. Strategic management: An analysis of its representation and focus in recent hospitality research. Int. J. Contemp. Hosp. Manag. 2011, 23, 439-462. [CrossRef]

114. Litvin, S.W.; Hoffman, L.M. Responses to consumer-generated media in the hospitality marketplace: An empirical study. J. Vacat. Mark. 2012, 18, 135-145. [CrossRef]

115. Jeong, M.; Mindy Jeon, M. Customer Reviews of Hotel Experiences through Consumer Generated Media (CGM). J. Hosp. Leis. Mark. 2008, 17, 121-138. [CrossRef]

116. Gensler, S.; Völckner, F.; Liu-Thompkins, Y.; Wiertz, C. Managing Brands in the Social Media Environment. J. Interact. Mark. 2013, 27, 242-256. [CrossRef]

117. Seth, G. Analyzing the Effects of Social Media on the Hospitality Industry. Master's Thesis, Graduate College, UNLV, Las Vegas, NV, USA, 2012.

118. Mia, L.; Gadenne, D.; Winata, L.; Sands, J.; Hooi, G. The influence of sustainability performance management practices on organisational sustainability performance. J. Account. Organ. Chang. 2012, 8, 210-235.

119. Hanaysha, J.R. Impact of Social Media Marketing, Price Promotion, and Corporate Social Responsibility on Customer Satisfaction. Jindal J. Bus. Res. 2017, 6, 132-145. [CrossRef]

120. Spillan, J.; Parnell, J. Marketing Resources and Firm Performance Among SMEs. Eur. Manag. J. 2006, 24, 236-245. [CrossRef]

121. Phillips, P.P.; Stawarski, C.A. Data Collection: Planning for and Collecting All Types of Data; Wiley: Toronto, ON, Canada, 2016.

122. Sekaran, U.; Bougie, R. Research Methods for Business: A Skill Building Approach; John Wiley \& Sons: Hoboken, NJ, USA, 2016.

123. Junaid, M.; Malik, R.N.; Pei, D.-S. Health hazards of child labor in the leather products and surgical instrument manufacturing industries of Sialkot, Pakistan. Environ. Pollut. 2017, 226, 198-211. [CrossRef] 
124. Fursova, J. The 'business of community development' and the right to the city: Reflections on the neoliberalization processes in urban community development. Community Dev. J. 2016, 53, 119-135. [CrossRef]

125. Hall, P.C.M.; Müller, D.K.; Saarinen, P.J. Nordic Tourism: Issues and Cases; Channel View Publications: Bristol, UK, 2008.

126. Hair, J.F.; Hult, G.T.M.; Ringle, C.; Sarstedt, M. A Primer on Partial Least Squares Structural Equation Modeling (PLS-SEM); SAGE Publications: London, UK, 2016.

127. Wise, K.A.G.D.S. ICIE 2016. In Proceedings of the 4th International Conference on Innovation and Entrepreneurship ICIE-2016, Toronto, ON, Canada, 28-29 April 2016.

128. Wan Afthanorhan, W.M.A.B. A Comparison Of Partial Least Square Structural Equation Modeling (PLS-SEM) and Covariance Based Structural Equation Modeling (CB-SEM) for Confirmatory Factor Analysis. Int. J. Eng. Sci. Innov. Technol. (IJESIT) 2013, 2, 198-205.

129. Astrachan, C.B.; Patel, V.K.; Wanzenried, G. A comparative study of CB-SEM and PLS-SEM for theory development in family firm research. J. Fam. Bus. Strategy 2014, 5, 116-128. [CrossRef]

130. Hair, J.F.; Sarstedt, M.; Ringle, C.M.; Gudergan, S.P. Advanced Issues in Partial Least Squares Structural Equation Modeling; SAGE Publications: London, UK, 2017.

131. Henseler, J.; Ringle, C.M.; Sarstedt, M. A new criterion for assessing discriminant validity in variance-based structural equation modeling. J. Acad. Mark. Sci. 2015, 43, 115-135. [CrossRef]

132. Peterson, R.; Kim, Y. On the Relationship Between Coefficient Alpha and Composite Reliability. J. Appl. Psychol. 2013, 98, 194-198. [CrossRef]

133. Cohen, J. Statistical Power Analysis for the Behavioral Sciences; Taylor \& Francis: Oxfordshire, UK, 2013.

134. Tenenhaus, M.; Vinzi, V.E.; Chatelin, Y.-M.; Lauro, C. PLS path modeling. Comput. Stat. Data Anal. 2005, 48, 159-205. [CrossRef]

135. Chen, F.F. Sensitivity of Goodness of Fit Indexes to Lack of Measurement Invariance. Struct. Equ. Model. Multidiscip. J. 2007, 14, 464-504. [CrossRef]

136. Brown, T.A. Confirmatory Factor Analysis for Applied Research; Guilford Publications: New York City, NY, USA, 2006.

137. Durdyev, S.; Ismail, S.; Ihtiyar, A.; Abu Bakar, N.F.S.; Darko, A. A partial least squares structural equation modeling (PLS-SEM) of barriers to sustainable construction in Malaysia. J. Clean. Prod. 2018, 204, 564-572. [CrossRef]

138. Sano, K.; Sano, H. The Effect of Social Media on Customer Satisfaction and Relationship Strength in a Service with High Perceived Risk in Japan. In Celebrating America's Pastimes: Baseball, Hot Dogs, Apple Pie and Marketing? Springer International Publishing: Cham, Switzerland, 2016; pp. 435-439.

139. Sanclemente-Téllez, J.C. Marketing and Corporate Social Responsibility (CSR). Moving between broadening the concept of marketing and social factors as a marketing strategy. Span. J. Mark. ESIC 2017, 21, 4-25. [CrossRef]

140. Go, E.; You, K.H. But not all social media are the same: Analyzing organizations' social media usage patterns. Telemat. Inform. 2016, 33, 176-186. [CrossRef]

141. El-Adly, M.I. Modelling the relationship between hotel perceived value, customer satisfaction, and customer loyalty. J. Retail. Consum. Serv. 2018, in press. [CrossRef]

142. Wolter, J.S.; Bock, D.; Smith, J.S.; Cronin, J.J. Creating Ultimate Customer Loyalty Through Loyalty Conviction and Customer-Company Identification. J. Retail. 2017, 93, 458-476. [CrossRef]

143. Choi, B.; Lee, I. Trust in open versus closed social media: The relative influence of user- and marketer-generated content in social network services on customer trust. Telemat. Inform. 2017, 34, 550-559. [CrossRef]

144. Song, X.M.; Parry, M.E. A Cross-National Comparative Study of New Product Development Processes: Japan and the United States. J. Mark. 1997, 61, 1-18. [CrossRef]

145. Arıkan, E.; Güner, S. The Impact of Corporate Social Responsibility, Service Quality and Customer-company Identification on Customers. Procedia Soc. Behav. Sci. 2013, 99, 304-313. [CrossRef]

146. Elving, W.J.L.; May Postma, R. Social Media: The Dialogue Myth? How Organizations Use Social Media for Stakeholder Dialogue. In How Strategic Communication Shapes Value and Innovation in Society; Emerald Publishing Limited: Bingley, UK, 2017.

147. Seo, E.-J.; Park, J.-W. A study on the effects of social media marketing activities on brand equity and customer response in the airline industry. J. Air Transp. Manag. 2018, 66, 36-41. [CrossRef] 
148. Rishi, B.; Bandyopadhyay, S. Contemporary Issues in Social Media Marketing; Taylor \& Francis: Oxfordshire, UK, 2017.

149. Abbas, J.; Aqeel, M.; Abbas, J.; Shaher, B.; Jaffar, A.; Sundras, J.; Zhang, W. The moderating role of social support for marital adjustment, depression, anxiety, and stress: Evidence from Pakistani working and nonworking women. J. Affect. Disord. 2019, 244, 231-238. [CrossRef]

150. Abbas, J.; Aman, J.; Nurunnabi, M.; Bano, S. The Impact of Social Media on Learning Behavior for Sustainable Education: Evidence of Students from Selected Universities in Pakistan. Sustainability 2019, 11, 1683. [CrossRef]

151. Aragón-Correa, J.A.; Sharma, S. A Contingent Resource-Based View of Proactive Corporate Environmental Strategy. Acad. Manag. Rev. 2003, 28, 71-88. [CrossRef]

152. Delmas, M.; Hoffmann, V.H.; Kuss, M. Under the Tip of the Iceberg: Absorptive Capacity, Environmental Strategy, and Competitive Advantage. Bus. Soc. 2011, 50, 116-154. [CrossRef]

153. Anderson, B.S.; Kreiser, P.M.; Kuratko, D.F.; Hornsby, J.S.; Eshima, Y. Reconceptualizing entrepreneurial orientation. Strateg. Manag. J. 2015, 36, 1579-1596. [CrossRef]

154. Gan, B.C.; Oke, A.; McDonald, S.; Fraser, S.S.; Anderson, A.R. A review of research methods in entrepreneurship 1985-2013. Int. J. Entrep. Behav. Res. 2015, 21, 291-315.

155. Wales, W.J. Entrepreneurial orientation: A review and synthesis of promising research directions. Int. Small Bus. J. 2015, 34, 3-15. [CrossRef]

156. Dyer, J.H.; Nobeoka, K. Creating and managing a high-performance knowledge-sharing network: The Toyota case. Strateg. Manag. J. 2000, 21, 345-367. [CrossRef]

157. Rodrigo-Alarcón, J.; García-Villaverde, P.M.; Ruiz-Ortega, M.J.; Parra-Requena, G. From social capital to entrepreneurial orientation: The mediating role of dynamic capabilities. Eur. Manag. J. 2018, 36, 195-209. [CrossRef]

158. Lin, Y.; Wu, L.-Y. Exploring the role of dynamic capabilities in firm performance under the resource-based view framework. J. Bus. Res. 2014, 67, 407-413. [CrossRef]

159. Tseng, S.-M.; Lee, P.-S. The effect of knowledge management capability and dynamic capability on organizational performance. J. Enterp. Inf. Manag. 2014, 27, 158-179. [CrossRef]

160. Anwar ul Haq, M.; Anjum, Z.-U.-Z.; Hussain, N.; Usman, M. Entrepreneurial activity in China and Pakistan: A GEM data evidence. J. Entrep. Emerg. Econ. 2014, 6, 179-193. [CrossRef]

161. Aminu, M.I.; Mahmood, R. Mediating Role of Dynamic Capabilities on the Relationship between Intellectual Capital and Performance: A Hierarchical Component Model Perspective in PLS-SEM Path Modeling. Res. J. Bus. Manag. 2015, 9, 443-456. [CrossRef]

162. Hussain, T.; Abbas, J.; Wei, Z.; Nurunnabi, M. The Effect of Sustainable Urban Planning and Slum Disamenity on The Value of Neighboring Residential Property: Application of The Hedonic Pricing Model in Rent Price Appraisal. Sustainability 2019, 11, 1144. [CrossRef]

163. Abbas, J.; Aqeel, M.; Zhang, W.; Aman, J.; Zahra, F. The moderating role of gender inequality and age among emotional intelligence, homesickness and development of mood swings in university students. Int. J. Hum. Rights Healthc. 2018, 11, 356-367. [CrossRef]

164. Anjum, M.N.; Bi, X.; Abbas, J.; Zhang, S.; McMillan, D. Analyzing predictors of customer satisfaction and assessment of retail banking problems in Pakistan. Cogent Bus. Manag. 2017, 4. [CrossRef]

(C) 2019 by the authors. Licensee MDPI, Basel, Switzerland. This article is an open access article distributed under the terms and conditions of the Creative Commons Attribution (CC BY) license (http://creativecommons.org/licenses/by/4.0/). 